\title{
The Economic Impact of the COVID-19 Pandemic on Ethnic Minorities in Manchester
}

DOI:

http://dx.doi.org/10.2139/ssrn.3949593

\section{Document Version}

Final published version

Link to publication record in Manchester Research Explorer

\section{Citation for published version (APA):}

Allen, R., Winiowski, A., Aparicio-Castro, A., Olsen, W., \& Islam, M. (2021). The Economic Impact of the COVID-19 Pandemic on Ethnic Minorities in Manchester. https://doi.org/10.2139/ssrn.3949593

\section{Citing this paper}

Please note that where the full-text provided on Manchester Research Explorer is the Author Accepted Manuscript or Proof version this may differ from the final Published version. If citing, it is advised that you check and use the publisher's definitive version.

\section{General rights}

Copyright and moral rights for the publications made accessible in the Research Explorer are retained by the authors and/or other copyright owners and it is a condition of accessing publications that users recognise and abide by the legal requirements associated with these rights.

\section{Takedown policy}

If you believe that this document breaches copyright please refer to the University of Manchester's Takedown Procedures [http://man.ac.uk/04Y6Bo] or contact uml.scholarlycommunications@manchester.ac.uk providing relevant details, so we can investigate your claim.

\section{OPEN ACCESS}




\section{The Economic Impact of the} COVID-19 Pandemic on Ethnic

\section{Minorities in Manchester}

\section{A Rapid Review}

\section{MANCHESTER 1824}

The University of Manchester

\section{MANCHESTER \\ 1824}

The University of Mancheste

\section{Policy@Manchester}

\section{MANCHESTER}

CITY COUNCIL

25 October 2021

Ruth Allen ${ }^{1}$

Arkadiusz Wiśniowski ${ }^{1,}{ }^{*}$

Andrea Aparicio Castro ${ }^{1}$

Performance, Research and Intelligence ${ }^{2}$

Wendy Olsen ${ }^{1}$

Maydul Islam ${ }^{3}$

${ }^{1}$ Social Statistics Department, University of Manchester

${ }^{2}$ Manchester City Council

${ }^{3}$ Policy@Manchester, University of Manchester

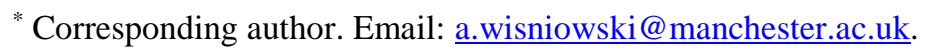

Acknowledgement: The authors gratefully acknowledge support from Policy@ Manchester within The University of Manchester, as part of the QR SPF grant monies allocation from UKRI Research England. 


\section{Table of Contents}

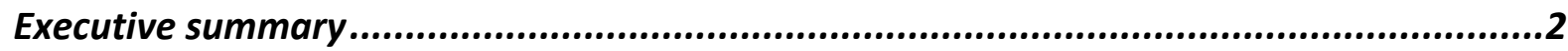

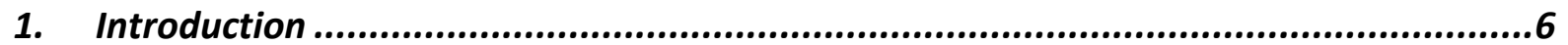

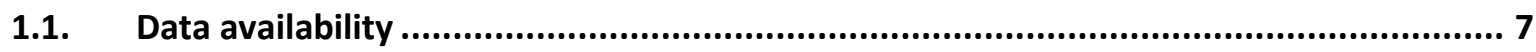

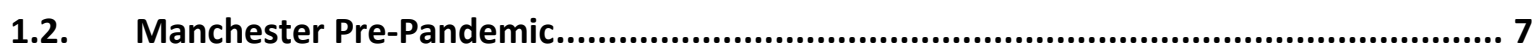

1.3. COVID-19 transmission and mortality amongst BAME population ................................12

2. Impacts of COVID-19 Restrictions and Lockdowns on the Economy.........................16

2.1. Changes in Employment Circumstances ........................................................19

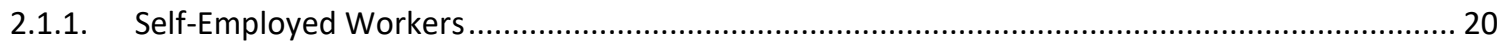

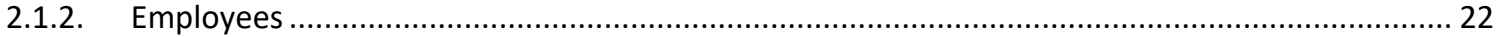

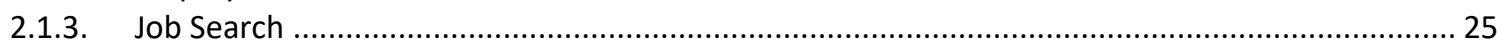

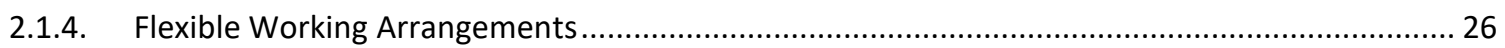

2.2. Personal Finances and Financial Security..........................................................27

2.2.1. Access to Benefits / Universal Credit .................................................................................. 29

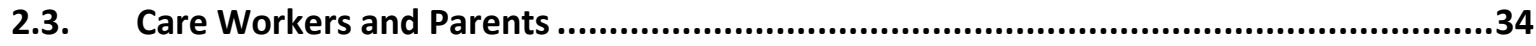

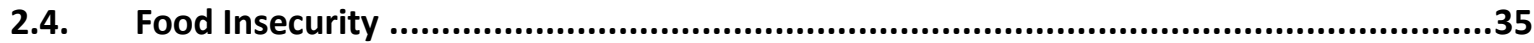

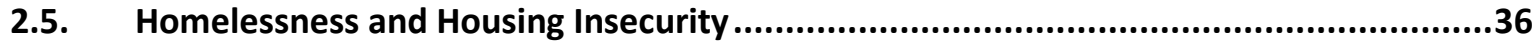

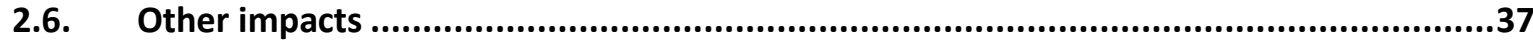

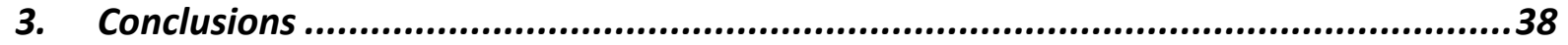

4. Recommendations..................................................................................39

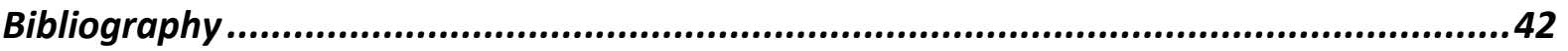

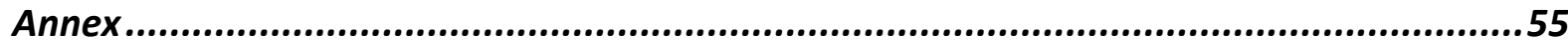

A Data Sources ...................................................................................................55

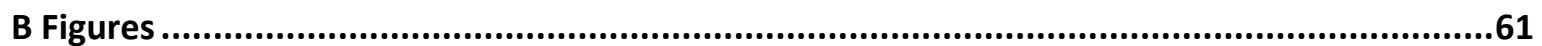




\section{Executive summary}

\section{Background}

Manchester is the sixth most deprived Local Authority in England (according to 2019 English Indices of Multiple Deprivation). As a consequence, many neighbourhoods and communities in the city were always going to be less resilient to the economic shock caused by the pandemic compared with other, less-deprived, parts of the country. Particular challenges for Manchester include the prevalence of:

- Poor health,

- Low paid work,

- Low qualifications,

- Poor housing conditions and overcrowding.

Ethnic minority groups also faced disparities long before the onset of the pandemic:

- Within the UK, ethnic minorities have been found to be most disadvantaged in terms of employment and housing - particularly in large urban areas containing traditional settlement areas for ethnic minorities.

- All Black, Asian, and Minority Ethnic (BAME) groups in Greater Manchester have been found to be less likely to be employed pre-COVID-19 than White people.

- People of Pakistani and Bangladeshi ethnic backgrounds, especially women, have the lowest levels of employment in Greater Manchester.

- Unprecedented cuts to public spending as a result of austerity have also disproportionately affected women of an ethnic minority background alongside women, disabled people, the young and those with no or low-level qualifications.

This environment has created and sustained a multiplicative disadvantage for Manchester's ethnic minority residents through the course of the COVID-19 pandemic.

\section{Impact of COVID-19}

Those most likely to have been exposed to financial stressors pre-pandemic are also most likely to have faced disproportionate impacts on their financial wellbeing a result of the lockdown.

Sectoral impacts:

- Job losses have been greatest in shutdown sectors such as hospitality and retail, accommodation, leisure and tourism, and personal care activities.

- Pakistani and Bangladeshi minorities are highlighted as being at heightened risk of vulnerability as a result of these groups constituting $30 \%$ of workers in shutdown sectors prior to the onset of COVID-19.

\section{Unemployment:}

- According to the UKHLS COVID-19 survey, BAME migrants in the UK are more likely to have experienced job loss, whilst BAME natives are less likely to enjoy employment protection such as furloughing, compared to UK-born White British respondents. In Manchester, there have been significant increases in the numbers claiming 
unemployment benefits in neighbourhoods with high proportions of BAME populations.

- However, ethnic minority individuals and women were less likely to have been furloughed or dismissed from work because these groups are more frequently employed in essential occupations as key workers. Black people represented a strong majority of key workers across all quintiles of earnings distribution. Increased exposure to the virus itself is therefore another vulnerability faced disproportionately by BAME individuals.

- Black youths have seen the largest unemployment rate, reaching $42 \%$ in OctoberDecember 2020.

\section{Insecure work:}

- Those in insecure work are 1.5 times more likely to have been made redundant than other working age adults.

- People from ethnic minority backgrounds represent a disproportionate percentage of the insecure workforce, with $18 \%$ of all insecure workers being BAME, despite these groups making up $11 \%$ of the total workforce.

- In particular, Black people are over twice as likely to be in temporary work, and the percentage of the Black workforce on zero-hour contracts is almost double the average ( 1 in 20 versus an average of 1 in 36).

\section{Self-employed workers:}

- There have been large declines in self-employment levels in the UK compared to 2016.

- In Greater Manchester one in four Pakistani and one in five Bangladeshi people of working age are self-employed. These groups are therefore disproportionately exposed to the ramifications of COVID-19.

Access to benefits / Universal Credit:

- Manchester has seen vast increases in claimants for universal credit across all ten boroughs, with a surge of 90\% between March and July 2020.

- Analysis of Universal Credit claimant count data in Manchester between May and December 2020 reveals that four of the five LSOAs with the largest increases have majority BAME populations.

- This is true for both in- and out-of-work claimants, suggesting that employment does not guarantee financial stability for these groups.

Homelessness:

- The Government provided additional funding to get rough sleepers off the street during the pandemic.

- The most vulnerable groups are those in emergency accommodation with no recourse to public funds (NRPF) because of their immigration status, who may have lost work throughout the pandemic and who do not qualify for the Coronavirus Job Retention or Self-employment Income Support Schemes.

Health and Transmission: 
- Early in the pandemic, large disparities in infection and mortality rates were observed for BAME individuals across the country.

- Death rates in people known to have COVID-19 were twice as high among those of a Bangladeshi background and $10-50 \%$ higher among other ethnic groups compared to White British people.

\section{Recommendations}

Challenges in Manchester are largely the same as before, but they have been accentuated by COVID-19.

- Policy response should consider the disadvantages faced by concentrations of ethnic minority workers in shut-down sectors, low paid work, and in insecure work, then aim to create better working conditions and more security for those employed in these types of work.

- Targeted interventions are required to aid economic recovery for Bangladeshi and Pakistani groups, who are represented in high numbers in self-employment and/or in shutdown sectors, together with a higher prevalence of single-earner households and higher likelihood of having dependent children.

- Further, identification of needs in terms of digital skills and access to ICT, and subsequent upskilling Manchester's population should also be a priority; this may be targeted specifically at the older working age population from ethnic minorities.

- Interventions in job searching and support in unemployment are needed for Black youths (aged 16-24) who are at highest risk of unemployment.

- Greater investment in affordable and social housing to prevent overcrowding is needed, which has been identified as more prevalent in ethnic minority populations.

- Also necessary is specific support for ethnic minorities alongside migrant populations via an information campaign on access to benefits, social housing and other services, perhaps in the native language.

- There is a need to remove restrictions for, or identify ways to protect, groups with "No Recourse to Public Funds" to prevent homelessness.

- The lack of timely data at lower geographical levels, especially for ethnic minority groups, creates difficulties in providing targeted aid in response to the pandemic. This lack of data presents a significant gap that must be addressed to effectively mitigate the economic fallout of COVID-19 for those who most need it. 


\begin{abstract}
This rapid review summarises the economic impacts of the pandemic on ethnic minorities, focusing on the city of Manchester. It utilises multiple reporting sources to explore various dimensions of the economic shock in the UK, linking this to studies of pre-COVID-19 economic and ethnic composition in Manchester and in the combined authority area of Greater Manchester. We then make inferences about the pandemic's impact specific to the city region. Greater Manchester has seen some of the highest rates of COVID-19 and as a result has faced particularly stringent 'lockdown' regulations.
\end{abstract}

Manchester is the sixth most deprived Local Authority in England (according to 2019 English Indices of Multiple Deprivation). As a consequence, many neighbourhoods in the city were always going to be less resilient to the economic shock caused by the pandemic compared with other, less-deprived, areas. Particular challenges for Manchester include the prevalence of poor health, low-paid work, low qualifications, poor housing conditions and overcrowding. Ethnic minority groups also faced disparities long before the onset of the pandemic. Within the UK, ethnic minorities have been found to be most disadvantaged in terms of employment and housing - particularly in large urban areas containing traditional settlement areas for ethnic minorities. Further, all Black, Asian, and Minority ethnic (BAME) groups in Greater Manchester have been found to be less likely to be employed prepandemic compared with White people. For example, people of Pakistani and Bangladeshi ethnic backgrounds, especially women, have the lowest levels of employment in Greater Manchester. Finally, unprecedented cuts to public spending as a result of austerity have also disproportionately affected women of an ethnic minority background alongside women, disabled people, the young and those with no or low-level qualifications. This environment has created and sustained a multiplicative disadvantage for Manchester's ethnic minority residents through the course of the COVID-19 pandemic. 


\section{Introduction}

Whilst the COVID-19 pandemic has undoubtedly affected lives universally, it is now clear that early decrees that the pandemic would be 'a great leveller' (Milne, 2020) were imprudent. Across geographies and between individuals, it is evident that the impacts of the pandemic have been asymmetrically distributed.

This rapid review aims to summarise the economic impacts of the pandemic on ethnic minorities, with a focus on the city of Manchester. It utilises multiple articles and reports to explore various dimensions of the economic shock in the UK, linking this to studies of pre-COVID-19 economic and ethnic composition in Manchester and in the combined authority area of Greater Manchester ${ }^{1}$, in order to infer the pandemic's impact specific to the city region. At the time of preparing this report, Greater Manchester has seen some of the highest rates of COVID-19 and as a result has faced particularly stringent lockdown regulations, with most of Greater Manchester's Middle Layer Super Output Areas (MSOAs) experiencing less than a month without enhanced restrictions since the pandemic began (Timms et al., 2020).

In this report, we use term 'ethnic minorities' to denote all ethnic groups other than White British². That is, ethnic minorities including Other White and Roma, Gypsy and Irish Travellers. The BAME category includes Black, Asian and minority ethnic groups. The use of this category is discouraged as it is problematic due to the unclear definition and focus on

\footnotetext{
${ }^{1}$ The Greater Manchester Combined Authority (GMCA) is made up of the ten Greater Manchester councils (Bolton, Bury, Manchester, Oldham, Rochdale, Salford, Stockport, Tameside, Trafford and Wigan) and Mayor. ${ }^{2}$ https://www.ethnicity-facts-figures.service.gov.uk/style-guide/writing-about-ethnicity; see also 2021 Census ethnicity classification at https://www.ons.gov.uk/census/censustransformationprogramme/consultations/the2021censusinitialviewonconte ntforenglandandwales/the2021censusethnicgroupstakeholderfollowupsurvey/furtherinformationthe2021censuset hnicgroupstakeholderfollowupsurvey.
} 
skin colour (Khunti et al. 2020). Where possible, we refer to specific minorities rather than to broader categories.

\subsection{Data availability}

Interventions to mitigate the economic effects of the pandemic and the lockdown and their evaluation require timely, frequent and precise data on economic and financial situation. These data should be available for small geographies (such as Upper Tier Local Authority or smaller) and disaggregated by key characteristics, such as ethnicity. Some data sources are available at low geographies. For example, the Claimant Count and Flow data are the counts of Universal Credit and Job Seekers Allowance claimants broken down by sex, age and type of benefit claimed (see Annex 1). They are available monthly via the Nomis database for Lower Layer Super Output Areas (LSOAs) but without information on the ethnicity of claimants (see Figures 1 and 2).

Other measures of economic impacts of the pandemic, disaggregated by ethnicities and small geographies, are available from surveys (see Annex A for a brief overview). However, these typically come with delays, which hinders design of timely interventions, and suffers from sampling and non-sampling errors. Therefore, this review focuses on findings related to ethnic minorities on national and regional scales, as well as pre-pandemic analyses that used small geographies. Where available, we refer to the data for Manchester, as well as for other geographies, to illustrate the situation of ethnic minorities in the period immediately preceding the pandemic.

\subsection{Manchester Pre-Pandemic}

Manchester, along with a further three of Greater Manchester's Districts (Oldham, Rochdale and Salford), appeared in a table of 20 local authorities (LAs) with the highest proportion of LSOAs in the most deprived $10 \%$ nationally on the Index of Multiple 
Deprivation (IMD) in 2019 (Penney, 2019). Further, ONS data on Gross Disposable Household Income (GDHI; calculated per head of population at current basic prices) for 2018 also showed that Manchester had a third largest average annual growth of GDHI (ONS 2020d). Nevertheless, it was the poorest Local Authority in Greater Manchester city-region, with $£ 14,864$, followed by Oldham and Rochdale (idem.).

Investigating the economic resilience of UK regions in the context of the recovery from the 2007/8 global financial crisis, Sensier and Devine (2020) noted that Greater Manchester scored slightly higher for resilience than the rest of the North West due to its strong employment growth, despite subdued productivity growth. However, Hincks's (2017) analysis of neighbourhood change, which focused on deprived neighbourhoods (LSOAs) across Greater Manchester, found that the most deprived neighbourhoods were likely to respond with more volatility to economic shocks when compared with less-deprived neighbourhoods.

Further, Hughes and Lupton (2018) analysed neighbourhood change in Greater Manchester, finding that deprived neighbourhoods are undergoing changes in opportunities for income, housing, and employment as well as migration and ethnic composition. However, low qualifications, poor health and caring commitments were all found to be much more salient issues in Greater Manchester's most deprived neighbourhoods than changes in patterns of residential mobility.

Lupton et al. (2016) highlighted low paid work as a substantial issue for the labour market in Greater Manchester. In their report on inclusive growth in the area, they noted that in $2015,23.2 \%$ of jobs in Greater Manchester paid less than the UK Living Wage ${ }^{3}$.

\footnotetext{
${ }^{3}$ The Living Wage is calculated by the Resolution Foundation and is based on evidence about living standards in the UK. In 2015 this was $£ 7.85$ per hour.
} 
Similarly, Jeffery et al. (2018), in their qualitative study of work and welfare in Salford, consider low paid and precarious work and the introduction of Universal Credit as detrimental to equal opportunities in the area. The authors drew attention to the polarisation of occupational growth in the area, noting that increases in the lowest ranked occupations from $12.6 \%$ in 2004 to $17.1 \%$ in 2016 are in stark contrast to the simultaneous increases in 'managerial, professional, [and] technical' sectors, which in 2016 accounted for $37.3 \%$ of all jobs in Salford. However, this increase may be attributed to the jobs created by the Media City at Salford Quays that was developed over 2007-2011.

It is perhaps pertinent that four of the six areas with the lowest average household incomes, (Manchester, alongside Bolton, Rochdale and Oldham) contain wards with ethnic minority populations making up $20-60 \%$ of the population (Jivraj, 2013). They also have between $24-43 \%$ of their respective LSOAs ranked as in the most deprived $10 \%$ in England (Penney, 2019). Within the UK, ethnic minority groups have been found to be most disadvantaged in terms of employment and housing, particularly in large urban areas containing traditional settlement areas for ethnic minorities (Lymperopoulou and Finney, 2016). This is reflected in the Greater Manchester pre-pandemic labour market where all BAME groups were less likely to be employed than White people (Elahi, 2017). People of Pakistani and Bangladeshi ethnic background, especially women, have the lowest levels of employment in Greater Manchester (ibid).

Lombard's (2021) qualitative study of low-income economic migrants' experiences of housing precarity in Manchester gave a voice to the subjects of such reports. Many interviewees reported tolerating poor housing conditions and overcrowding as a means to attain future housing objectives such as saving for a deposit. This type of inequity is crucial to understanding the disproportionate impact of the pandemic on ethnic minorities. $11 \%$ of 
non-White British households in the North West were overcrowded over the period April 2016-March 2019, in comparison to $1 \%$ of White households, with the rate of overcrowding for Bangladeshi, Pakistani, and Black African households at $24 \%, 18 \%$ and $16 \%$ respectively (ONS, 2020a). Such numbers demonstrate these groups are disproportionately exposed to the risk of contracting the virus from a member of their household due to the unfeasibility of social distancing within the home.

As of 31 March 2020, there were 15,689 Local Authority-owned dwellings in Manchester, out of which 40 were in affordable rent (i.e. around $80 \%$ of the market rent), and the rest are rented socially. Between April 2019 and March 2020, there were 36 new builds or conversions (DLUHC 2020). It was a slight decrease as compared with 31 March 2019 (due to sales by using Right to Buy), when there were 15,845 dwellings, and the stock increased by 91 dwellings. Meanwhile, English Housing Survey 2016-18 (Ministry of Housing, Communities and Local Government, 2020) revealed that, in England, the percentages of households that rented social housing were highest for Black African (44\%), Mixed White/Black African (41\%), Black Caribbean (40\%) and Bangladeshi (33\%), as compared with $16 \%$ for the White British people. North West also had the second largest (after London) proportion of people "Other than British White" renting social housing (21\%), as compared with White British (17\%) (idem.).

Whilst the inequalities found in Greater Manchester's labour market pre-COVID-19 reflect the structural inequalities underpinning society at a national level, Manchester's residents are also impacted by interregional inequality. Prior to the onset of the pandemic, the UK was found to be one of the most unbalanced countries in the industrialised world in terms of interregional inequality, when assessed by multiple measures including Gross Domestic Product (GDP) per capita, regional Gross Value Added (GVA) per capita and 
Regional Disposable Income (RDI) per capita (McCann, 2020). Inequality in the UK was more apparent in regional comparisons than those between urban and non-urban areas (McCann, 2016). There is a clear North-South divide, with 15 out of the 20 most deprived areas in the UK in 2019 being in the North or Midlands, according to the IMD (Penney, 2019).

These most deprived areas have historically not felt the rewards of globalization and national economic growth, fuelling a feeling of being 'left behind' which many cite as a primary reason behind the result of the EU Referendum in 2016 (Goodwin and Heath, 2016). The government has faced criticism for this disparity for decades. To enable local authorities to address the issues facing their communities, the government has recently committed to 'levelling up'. The Levelling Up Fund of $£ 4.8 \mathrm{bn}$ focuses on the local infrastructure in the regions 'left behind' the UK and is a part of a broader package of the UK-wide interventions. ${ }^{4}$ Etherington and Jones (2017) provided a detailed analysis of Greater Manchester's devolution strategy, arguing that unprecedented cuts to public spending because of austerity $^{5}$ have undermined the extra funding given for the City Deal ${ }^{6}$. Comparing local authority funding from $2009 / 10$ to $2016 / 17$, they note budget gaps pointing to a loss of over f1bn. They stress that women, those of BAME ethnic background, disabled people, young people and those with no or low-level qualifications have been disproportionately affected by these cuts (cf. Sandhu \& Stephenson, 2015; Hall et al., 2017).

As ONS reported, despite the redistributive power of taxes and benefits, the gap between the richest and poorest income in the UK has widened over last 10 years (ONS,

4

https://assets.publishing.service.gov.uk/government/uploads/system/uploads/attachment_data/file/966138/Levell ing_Up_prospectus.pdf

${ }^{5}$ Introduced by the Conservative Party following the 2007-8 financial crisis, austerity measures affected numerous facets of public spending, including a reduction in spending on welfare via the Welfare Reform Act 2012 and reductions in local government funding.

${ }^{6}$ https://www.gov.uk/government/publications/city-deal-greater-manchester 
2021). The rise in inequality can also be attributed to the freeze on cash benefits in financial year ending 2016 (idem.).

In summary, it is evident that those of BAME background, as well as women and young people, faced disparities long before the onset of the pandemic. As Manchester is a relatively deprived area, ethnic minority people within Greater Manchester, and in Manchester specifically, face more deprivation and are in precarious situations. It is this environment that has created and sustained multiplicative disadvantage throughout the course of the COVID-19 pandemic.

\subsection{COVID-19 transmission and mortality amongst BAME population}

Greater Manchester had identifiable health inequalities prior to the pandemic, with one of the lowest life expectancies in England for both men and women (Institute of Health Equality, 2020). That the North West has had the highest percentage of its population shielding in the UK, at almost 5\% of the population (Marszalek \& Peytrignet, 2020), is therefore unsurprising. The links between socio-economic and health deprivation are clear (see, e.g., Nazroo, 2003; Bambra et al., 2011; Bambra et al. 2020b; Marmot, 2020). Further, since 28 September 2020, the government's regulations ${ }^{7}$ have required those tested positive with COVID-19 or had symptoms of COVID-19, and those in their households, as well as those notified by the NHS Test and Trace, to self-isolate for a period of 10 days. This regulation prompted the introduction of the Test and Trace Support Payment scheme in form of a $£ 500$ lump sum paid to those on low incomes and distributed upon application to local authorities. The government estimated just below four million people would be eligible for this payment (Kennedy \& Ferguson, 2021). However, as TUC's report shows (after

\footnotetext{
${ }^{7}$ Health Protection Regulations 2020; also https://www.gov.uk/government/publications/covid-19-stay-at-homeguidance/stay-at-home-guidance-for-households-with-possible-coronavirus-covid-19-infection (accessed 15/04/2021). The regulation applied in England and Wales but not in Scotland nor Northern Ireland.
} 
Kennedy \& Ferguson, 2021), the available funding falls short of the demand, with seven out of 10 applicants left without support and the estimated cost being more than twice the allocated budget ${ }^{8}$.

Ethnic minorities are at a higher risk of infection, mainly because they tend to live in urban areas, in overcrowded households, in deprived areas, and work in occupations with higher risks of transmission (e.g. Nazroo \& Becares, 2020). They may also be born abroad and thus face cultural and language barriers in accessing services (Public Health England 2020a). Further, some ethnic minorities may be at higher risk of poor outcomes once they acquire the infection due to the higher rates of pre-existing conditions, for example, the prevalence of hypertension is significantly higher for Afro-Caribbean and South Asian populations (Khan \& Beevers 2005; Public Health England 2020a).

The ONS data (ONS 2020e) showed that, in England, males of Bangladeshi and Black African ethnicity had the risk of death from COVID-19 almost twice as large as White population, after controlling for age, type of residence, geography, socio-economic status, household characteristics, occupational exposure, and health-related variables. For females in the same ethnic groups, the odds ratios were 1.51 and 1.34, respectively. There were also differences in how ethnic minorities were affected over time. In Wave One, risk of mortality was the highest for Black African (both males and females), whereas in Wave Two, it was for Bangladeshi, Pakistani and Indian minorities (idem.).

Public Health England (2020a; 2020b), by using the data from the ONS, also reported large disparities in infection and mortality rates for BAME individuals across the country. A review by Public Health England (2020a) suggested that death rates in those known to have

\footnotetext{
${ }^{8}$ https://www.tuc.org.uk/news/huge-demand-self-isolation-support-sees-councils-facing-big-funding-shortfalltuc-study.
} 
had COVID-19 were twice as high among those of a Bangladeshi background and $10-50 \%$ higher among other ethnic groups compared to White British people, after controlling for age, sex, deprivation and region. The report also found that Asian and Other ethnic groups were over-represented in the number of COVID-19 cases amongst nurses, midwives and nursing associates, as opposed to White and Black ethnic groups. Occupations that experienced significantly higher mortality than the rest of the population aged 20-64 were nursing auxiliaries and assistants, security guards and related occupations, and taxi and cab drivers and chauffeurs; however there is no breakdown of mortality by occupation and ethnicity (see also Williamson et al. 2020). Patel, P. et al. (2020) criticised this report for not including discussion and recognition of the structural inequalities which are fuelling the pandemic's disparate effects.

In May 2020, Patel, J. A., et al. (2020) urged policymakers to expand their definition of the vulnerable to include those with socioeconomic vulnerabilities, not only those with multiple comorbidities for the virus. They identified six factors putting those of low socioeconomic status (SES) at higher risk for exposure to COVID-19: 1) a higher likelihood of living in overcrowded housing; 2) employment in occupations with no scope to work from home; 3) unstable work conditions and incomes which affect mental health; 4) that those of lower SES present to healthcare at more advanced stages of illness; 5) barriers to accessing healthcare service including language barriers; 6) hypertension and diabetes as more common in poverty-stricken populations and ethnic groups (Khan \& Beevers 2005). Clift et al. (2020) have developed a so-called QCOVID - a prediction algorithm for the risk of hospital admission and mortality due to COVID-19. It takes into account, amongst other predictors, ethnicity and a Townsend deprivation score based on a patient's postcode. The Townsend score measures deprivation with unemployment, non-car ownership, non-home ownership 
and household overcrowding (Townsend \& Davidson, 1982). Bentley (2020) adds that ethnic disparities in incidence and outcome of the virus are a direct result of structural inequalities that disproportionately affect the BAME community, making them more susceptible to the aforementioned factors outlined by Patel, J. A. et al. (2020). Razai et al. (2021) assert that a discussion of ethnic disparities in COVID-19 needs to consider the effect of cultural and structural racism.

Indeed, a report from the Royal College of Nursing (2020) suggested that BAME health workers have been disadvantaged in access to PPE compared to their White counterparts. Meanwhile, a survey of 200 Asian doctors and nurses in Leicester in May 2020 found that more than $70 \%$ were anxious about their role (Moorthy and Sankar, 2020). Whilst a wider survey of almost 1,000 health and social care staff found that $50 \%$ felt their mental health had declined during the first two months of the pandemic (Quilter-Pinner et al., 2020), the study did not collect data regarding the ethnicity of respondents, leaving questions regarding racial/ethnic differences in the mental wellbeing of healthcare staff unanswered.

Tubadji et al. (2020) investigated COVID-19 mortality rates across England and Wales, finding evidence that they are consistent with the geography of economic deprivation. Areas with greater than average concentrations of non-White populations have experienced a fivepercentage-point higher death toll. These findings are in line with Nazroo and Becares (2020), Breen and Ermisch (2021) and Williamson et al. (2020). In particular, Williamson et al. (2020) found that Black and South Asian people have been at higher risk of dying compared with those of White ethnicity. The authors note that the virus appears to be hitting more deprived and more diverse areas the hardest. Sá (2020) conducts a similar 
geographical analysis which largely confirms the findings of Tubadji et al., adding that areas with large households and greater use of public transport also have higher infection rates.

Prats-Uribe et al. (2020) attempt to disentangle socioeconomic deprivation and prior comorbidities in understanding the factors behind BAME communities' higher rates of infection utilising UK Biobank data. Their findings indicate that Asian/Asian British and 'Other' ethnic group participants had around double the infection risk of White participants. However, the UK Biobank slightly underrepresents ethnic minorities and people from socioeconomically deprived areas (Fry et al. 2017).

Breen and Ermisch (2020) similarly examined geographical variation in age and sexstandardised COVID-19 mortality rates across English local authorities between March and July, by using COVID-19 mortality rates for local authorities and Indices of Multiple Deprivation. Although areas with higher social deprivation have higher COVID-19 mortality rates, this association is not as strong as that between social deprivation and total mortality rate, whilst an area's non-white proportion of population is found to be strongly associated with COVID-19 mortality. This suggests there are differences in the relationship between socioeconomic factors and COVID-19 mortality when compared with non-COVID and past mortality. Nazroo and Becares (2020) also found that rates of COVID-19-related mortality within a local authority were higher when the proportion of ethnic minority population was higher. They explained that the reason for this are social and economic inequalities driven by entrenched structural and institutional racism and racial discrimination (idem.).

\section{Impacts of COVID-19 Restrictions and Lockdowns on the Economy}

The impact of the pandemic on the global economy has been well documented over the course of the year, with the shock evident across various measures of economic performance (e.g., Baker et al. 2020; Nicola et al. 2020; Maital \& Barzani 2020). Whilst the 
ramifications of the pandemic may be ubiquitous, the distribution of these consequences is not. Those more likely to be exposed to financial stressors such as income poverty, food poverty, and insecure employment pre-pandemic, are also more likely to have faced disproportionate impacts on their financial wellbeing as a result of the lockdown. Negative economic impacts have also been shown in the absence of the restrictions, for example, in South Korea (Aum et al. 2020).

Nicola et al. (2020) summarised the socio-economic consequences of COVID-19 on various aspects of the global economy, providing breakdowns across primary, secondary and tertiary sectors, government financial policy response and social impacts. They stress that it is crucial that the "whatever it takes" promise is truly delivered by governments. Susskind and Vines (2020) similarly recount the economic milestones of the pandemic and summarise the global changes in policy that have been put in place to counter the extreme impacts of the pandemic. In the UK, this included the following:

1. The Coronavirus Job Retention Scheme, which allows any employer in the UK to apply for a government grant to cover $80 \%$ of the wages (up to a total of $£ 2500$ per month) of employees who were not working but were "furloughed" and kept on payroll, rather than being dismissed (HM Treasury, 2020).

2. The Self-Employment Income Support Scheme, which allows self-employed individuals or partnerships to apply for a grant equalling $80 \%$ of three month's average trading profits, paid in a single instalment (capped at $£ 7,500$ in total) per quarter (HMRC, 2021).

3. An increase of $£ 20$ per week to the standard allowance in Universal Credit and the basic element in Working Tax Credit (DWP, 2021). 
As the economic response to the pandemic has differed by country, so too have the economic impacts. Adams-Prassl et al. (2020) presented real-time survey evidence from the UK, US and Germany, illustrating differential labour market impacts across the countries. It is evident from the analysis that respondents in Germany had faced much less of an impact on employment than their UK and US counterparts. For example, just 5\% of German workers had lost their jobs in early April, compared to $20 \%$ in the US and $17 \%$ in the UK. Further, female workers are more affected by job losses in the UK and US, but not in Germany - the authors attribute this to differences in care responsibilities.

Fana et al.'s (2020) analysis of employment across six European countries using EULFS data may shed some light on the results of Adams-Prassl et al.'s (2020) study. The authors underlined that the countries hardest hit by the virus (Spain, Italy and the UK) were also those most likely to suffer the worst implications of lockdown due to having a larger share of the workforce employed in shut down sectors, such as hospitality and retail; accommodation, leisure and tourism; and personal care activities. The authors drew attention to the fact that these labour markets were most vulnerable prior to the onset of the pandemic, "characterised by high unemployment and precarious work". Also, ethnic minorities were likely to be disproportionately represented in these sectors (Citizens Advice 2020; see also Sections 2.1.1 and 2.1.2).

Mayhew and Anand (2020) reviewed the policy responses of the UK government and their effect on the economy, using a literature review to make predictions on the ability of the UK economy to recover post-COVID-19. The authors predicted that the young would suffer disproportionately from a COVID-19-triggered recession, warning against policies which prioritise getting people into work over matching people to the right jobs, which have 
inadvertently contributed to unemployment scarring in the past. Work-based training and apprenticeships, and better training of work coaches were seen as solutions to this issue.

Bambra et al.'s (2020a) comprehensive report on the effect of COVID-19 on the northern cities of England covered impacts on productivity, mental and financial wellbeing, economic crises, health, and children. The report noted the consequences of the NorthSouth divide on the ability of the North to withstand the economic impact, stating that the COVID-19 pandemic puts the government's "levelling up" project in immediate danger, with prior inequalities between regions exacerbated by the pandemic.

\subsection{Changes in Employment Circumstances}

The data compiled by the ONS (2020c) data showed that Black youths (aged 16-24) experienced the largest unemployment rate throughout 2020, compared with the White population, in the UK. In October-December 2020, this rate was more than thrice larger (41.6\% compared with $12.4 \%)$. In the respective period for 2019 , the unemployment rates were $24.5 \%$ and $10.1 \%$ for Black and White youths, respectively. The second most affected group of youths were Pakistani (31.5\% in Oct-Dec 2020, as compared with $22.5 \%$ in Oct-Dec 2019). The unemployment rate for over 16 s was highest amongst Pakistani individuals, at 9.7\%, compared with 4.5\% for White and 7.6\% for Black population (Oct-Dec 2020).

Meanwhile, the unemployment rate in Manchester increased from 4.9\% in 2018 (January to December), through $6.2 \%$ in 2019 , to $8.7 \%$ in 2020. In the UK, the unemployment rate in these years was 4.2\%, 3.9\%, and 4.6\%, respectively ${ }^{9}$ (Annual Population Survey 2021). Further, $18.3 \%$ of all households in Manchester were jobless, as compared with $16.2 \%$ in Greater Manchester, and 13.3\% in England (idem.).

\footnotetext{
${ }^{9}$ Because these estimates are based on a Labour Force Survey/Annual Population Survey, the ones for Manchester come with much larger uncertainty; e.g., for 2020 the 95\% Confidence Interval was $(6.0 \%, 11.4 \%)$ for Manchester, and $(4.5 \%, 4.7 \%)$ for the UK.
} 


\subsubsection{Self-Employed Workers}

Data from the ONS Annual Population Survey shows that, in Manchester, in 2018 (January to December), $12.3 \%$ were self-employed, as compared with $15.0 \%$ in the UK. In 2020, this value in the UK fell to 14.0\%, whereas in Manchester - to 8.7\% (Annual Population Survey, 2021). However, it is important to note that there are considerable differences in self-employment by ethnic group. For instance, one in four Pakistani and one in five Bangladeshi people of working age are self-employed in England and Wales (Lawrence, 2020; Platt \& Warwick 2020). In 2018, self-employment in the whole of UK was most common in the combined Pakistani and Bangladeshi ethnic group, where $20.4 \%$ of workers were self-employed, while for the White people this percentage was $15.1 \%$. Further, $41 \%$ of workers from these two ethnic groups were in the three least skilled types of occupation, as compared with $24 \%$ for the White ${ }^{10}$.

Therefore, these ethnic groups are disproportionately exposed to the aforementioned ramifications of COVID-19 on the self-employed. This is of particular concern as Greater Manchester is home to large Pakistani and Bangladeshi communities, with large populations of these ethnic groups residing in Manchester as well as Rochdale and Oldham (ONS, 2012).

Yue \& Cowling (2020) found disproportionate effects on subjective wellbeing for the self-employed when compared with waged workers, linking this to the asymmetric government response in financial aid, which favoured waged employees and left around one million self-employed workers with no financial support (cf. Lawrence, 2020). The authors also highlighted a difference in the impact of a reduction in work hours on the wellbeing of

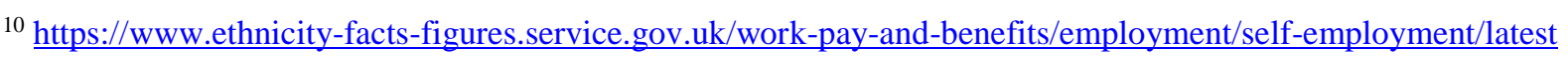
(accessed 29/05/21)
} 
the self-employed, indicating that they are attached to their work in a way that "transcends that of waged employees" (Yue \& Cowling, 2020:107).

Reuschke et al. (2020) used the Labour Force Survey to evaluate changes for selfemployed individuals during the first lockdown in the UK. Results imply large declines in selfemployment to levels seen in 2016 . The number of self-employed men decreased proportionately more than that of self-employed women. Analysis included numbers and change in self-employment by region (London saw the largest decline in self-employed workers during the period) as well as indicators of ethnic group. Black African, Black Caribbean and Black British people had the largest decreases in self-employment, with these groups seeing a reduction of two percentage points in April-June 2020, compared to the same period in 2019.

Further investigation into self-employment during 2020 using survey data collected by the London School of Economics and the Centre for Economic Performance (Blundell \& Machin, 2020) revealed that although self-employed men's work declined more than women's, this is due to self-employed women being able to work from home more frequently than self-employed men. For those able to work from home, women are more negatively affected than men. The authors also noted gaps in applications for financial assistance; higher-income workers were more likely to apply for the Coronavirus Selfemployment Income Support Scheme. These findings are mirrored in evidence from one business owner interviewed in Lawrence's (2020) review of the disproportionate impact of COVID-19 on BAME communities, who conducted a survey which showed that $48 \%$ of BAMEled businesses did not apply for government schemes because they didn't think they would qualify. 


\subsubsection{Employees}

Nearly $50 \%$ of the jobs at risk during the first lockdown were in occupations paying less than $£ 10$ per hour (Allas et al., 2020). Furlough statistics indicated that $73 \%$ of those working in accommodation and food services were furloughed in the first half of April, whilst only $13 \%$ of those in information and communication experienced the same fate (ibid). The median gross hourly pay in these sectors in 2019 was $£ 8.60$ and $£ 19.20$ respectively (ibid). In a regional analysis, the authors find that regions with lower average income have a higher proportion of jobs at risk.

A skills analysis of Greater Manchester by New Economy (2017) found that information and communication jobs topped the list of growing employment sectors in the area. However, overall, jobs in Greater Manchester were lower skilled than typical in the UK, with particularly high concentrations of low skilled workers in Manchester, Oldham, Rochdale, Bolton and Wigan - areas which also have higher than average numbers of deprived LSOAs, and of which four have high percentage BAME populations.

Further, contributors to THINK's (2020) study of the economic impacts of the pandemic in Manchester emphasise training in digital skills as a method of supporting unemployed BAME individuals and over-50s in their return to the workforce. Indeed, while the UK's "digital divide", i.e., a difference between those who have access to information and communication technology (ICT) and those who do not, has narrowed over 2011-2018 especially for ethnic minorities (ONS 2019), there are still large differences between older and younger people. For example, $83.6 \%$ of Asian minority population in the UK aged 55-64 were users of the Internet in 2019 (January-March), compared with 93.5\% for the White population. For age group $65-74$, this was even lower, at $64.8 \%$, as compared with $83.8 \%$ for 
the White. ${ }^{11}$ However, digital exclusion is not only the access to the ICT, but also having sufficient skills in using, for example, online forms. This exclusion often comes together with language barriers, that are experienced by older people of non-White ethnicity, especially females (cf. Sandhu, 2016; Qureshi et al. 2020).

Crossley et al.'s (2020) study of labour market shocks and the steps that households took to cope with these finds that although $45 \%$ of individuals had experienced a loss of household earnings of at least $10 \%$, those from minority ethnic groups and those in the lowest two quintiles of average pre-COVID income suffered the worst labour market impacts. For those whose hours fell, BAME groups were 15 percentage points less likely to be supported by the Job Retention Scheme, and 13 percentage points more likely to have been made unemployed as a result of the pandemic. The median fall in earnings for the bottom quintile of earners was $13 \%$ by May, versus $2 \%$ for the top quintile. These groups also had higher rates of additional borrowing in order to mitigate these impacts.

Such findings contrast with Witteveen's (2020) analysis, which indicates that women were less likely to have been furloughed or dismissed from work, attributable to the fact that these groups are more frequently employed in essential occupations. For the ethnic minorities (classified as BAME), the author found no difference when compared to the White population, except for the middle tertile of earnings. The likely mechanism proposed as an explanation was the fact that ethnic minorities were also more likely to be employed in essential occupations. However, the analysis also did not test for possible moderation of the effect of being a BAME person with the type of employment or gender. Additionally, the

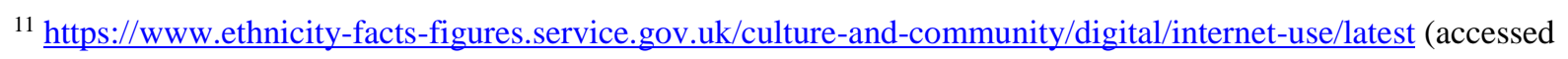
$30 / 04 / 21)$
} 
sample size was relatively small, with only $6.4 \%$ of the sample of 5,155 being BAME people (as compared with an estimated $14.4 \%$ for the UK).

Crawford et al. (2020) show that pre-pandemic, households in the top quintile of income distribution spent around a third of their expenditure on services affected by sector shutdowns, including transportation and hospitality and leisure, for example, personal care, restaurants, and culture. Blundell et al. (2020) make the salient point that these sector shutdowns have removed the livelihoods of many lower earners.

Findings from the Resolution Foundation's coronavirus survey largely confirm that it is the lowest paid who have borne the brunt of the economic impact of the pandemic (Gardiner and Slaughter, 2020). The authors found that around a third of lower-paid employees had lost their job or been furloughed as of May 2020, in comparison to around a tenth of top earners. Employees in atypical work, such as those on zero-hours contracts, were also more likely to have experienced job or hours losses or to have been furloughed.

This is confirmed with analysis from Citizens Advice (2020), which finds that those in insecure work are 1.5 times more likely to have been made redundant than other working age adults, and seven times more likely to have had informal redundancy discussions. People from ethnic minority backgrounds represent a disproportionate percentage of the insecure workforce, with $18 \%$ of all insecure workers being BAME, despite these groups making up $11 \%$ of the total workforce (ibid). In particular, the Black community is overrepresented in the insecure workforce. Black people are over twice as likely to be in temporary work, and the percentage of the Black workforce on zero-hour contracts is almost double the average (1 in 20 versus an average of 1 in 36) (TUC, 2017).

Whilst it is evident that BAME groups have faced disproportionate exposure to the hardships of the pandemic on aggregate, Platt and Warwick (2020) ascertain differential 
impacts of the pandemic between specific ethnic minority groups. The authors focus on the largest minority groups in England and Wales: White other, Indian, Pakistani, Bangladeshi, Black African and Black Caribbean. There is evidence of substantial variability between these groups, with White Other and Indian ethnic groups more comparable to White British in terms of economic vulnerability. In contrast, Bangladeshi and Pakistani men were highlighted as particularly at risk due to a prevalence of working in self-employment and shutdown sectors coinciding with high occurrence of single-earner households in these groups, meaning the impact of earnings losses may not be as easily withstood.

Blundell et al. (2020) similarly highlight Pakistani and Bangladeshi individuals as being at heightened risk of vulnerability as a result of these groups constituting $30 \%$ of workers in sectors shut down prior to the onset of COVID-19. Key workers are also disproportionately represented among ethnic minorities. In particular, Black people represented a strong majority of key workers across all quintiles of earnings distribution. Increased exposure to the virus itself is therefore another vulnerability faced disproportionately by BAME individuals.

\subsubsection{Job Search}

Arthur (2021) utilises data gathered from the online job platform Reed.co.uk to quantify the pandemic's effects on the labour market in the UK. Results show that although job postings rapidly fell in March, they have since slowly increased and as of January 2021 the number of posts per day has recovered to pre-crisis levels. In analysis of job advertisements per capita across the UK's NUTS2 administrative regions, this pattern is consistent, for example, despite the North West being the region worst affected by COVID19, the pattern of job postings is largely comparable to that of London. However, a clear North/South divide is present, with the number of advertisements by population showing a 
concentration in the South East. The authors note that potential regional differences in the use of Reed.co.uk as a job advertisement platform may influence these results.

In Manchester, advertised vacancies halved between May 2020 and July 2020

(THINK, 2020). Increases in the numbers claiming unemployment benefits in Manchester neighbourhoods with high proportions of BAME populations was reported to be a result of many residents in these areas losing work due to the closure of the night-time economy and hospitality sectors (ibid; see also Case Study in Section 2.2.1).

\subsubsection{Flexible Working Arrangements}

A report authored by Yasenov (2020) highlights that those with socioeconomic vulnerabilities are less likely to be able to work from home, including those with lower levels of education, ethnic minorities, lower-wage workers, and immigrants. Although the analysis is based on US data, the study brings to light another barrier to financial resilience during the pandemic, which simultaneously increases health risks for these groups, furthering vulnerability.

Interestingly, the ONS's (2020b) Coronavirus and Homeworking report, based on the prototype ONS Labour Market Survey, finds that, in the UK in April 2020, slightly higher proportions of ethnic minority groups were working from home. That is, $48.1 \%$ of people from ethnic minority groups reported some homeworking, compared to $46.4 \%$ of White people. However, slightly more of those in ethnic minority groups who worked from home said that COVID-19 was the main reason of working from home, at $87.3 \%$, compared with $85.8 \%$ for the White population. No detailed breakdown by specific ethnic groups nor geographies smaller than regions has been provided. 


\subsection{Personal Finances and Financial Security}

Brewer and Tasseva (2020) analyse the UK government's early policy response to COVID-19, estimating its impact on household incomes in April and May 2020 using microsimulation methods. Their estimations project average income losses of $6.9 \%$ for the UK households. They also posit that changes to Universal Credit, Job Seekers Allowance and the tax system would reduce the shock of the economic consequences of the pandemic.

Bhattacharjee and Lisauskaite (2020) obtain projections of the number of households in destitution in the UK using microsimulation methods, predicting that destitution is three times higher in the second quarter of 2020 than the non-COVID counterfactual level.

In contrast, nowcasts conducted by Bronka et al. (2020) from June 2020, based on the 2016 Input-Output data supplemented with the Labour Force Survey data, suggest that the intervention of the government would contain the reduction in average household disposable income from $-3 \%$ to $-1 \%$. Their predictions also point to a reduction in poverty of more than 1 percentage point relative to pre-COVID levels, due to increased Universal Credit, despite predictions of a reduction in employment of around $25 \%$ and a reduction in yearly GDP of around $2 \%$. However, these estimates are based on an eight-month timeline, where the duration of the income shock is expected to be two months of strict lockdown at $100 \%$ of the estimated effect, two months of partial lockdown at $50 \%$ of the estimated effect and a further four months in a recovery phase at $25 \%$ of the estimated effect.

Witteveen (2020) utilises the UKHLS COVID-19 survey (ISER 2021) to examine the extent to which various sociodemographic groups were exposed to economic hardship between March and May of 2020, finding that lower earning groups were over twice as likely to experience economic hardship when compared with the highest quintile earners. 
Gathergood et al. (2021) conducted a geographical analysis of consumer spending in the UK in the second half of 2020. The authors utilised Fable Data ${ }^{12}$, a real-time source of consumption data that contain postcode-level geo-tags for cardholder and store addresses. The authors found evidence of regional unbalance, with the strongest recovery in spending seen in the commuter belt areas in outer London and surrounding localities.

The social stratification of the impact of the pandemic and lockdown is highlighted in a study conducted by Mikolai et al. (2020). The study illustrates the presence of a multidimensional index of inequality that often intersects within households, particularly in those of working age. The study produces evidence of regional variation in household level vulnerabilities, indicating the need for a nuanced approach to mitigating the effects of the pandemic; however, they stress the need for further spatial disaggregation.

Mogaji (2020) identified early in the pandemic that financial vulnerability would be a key issue for countries and individuals due to the pandemic. The study highlighted the important role of the government as well as banks in supporting these individuals, drawing attention to the potentially harmful actions that can result from financial vulnerability, including gambling and the use of payday loans.

Indeed, a report from the Financial Conduct Authority (2020) found that between March and October 2020, the number of adults with characteristics of financial vulnerability increased by $15 \%$ compared to the February figure. In February 2020 , these adults were more than twice as likely to utilise high-cost credit options. Further, $38 \%$ of adults saw their financial situation worsen overall due to COVID-19, with particularly strong impacts on the self-employed, adults with a household income of less than $£ 15,000$ per year, and BAME adults.

\footnotetext{
${ }^{12}$ More information about these data is available at https://www.fabledata.com/.
} 
Benzeval et al. (2020) congruently utilised the UKHLS COVID-19 study (ISER 2021) to estimate the prevalence of mitigation strategies for the financial strain of the pandemic. These opportunities are most limited for those most in need. The study found that BAME individuals are more than twice as likely to have resorted to borrowing as the non-BAME population. Further, BAME individuals who lost hours due to the pandemic were 14 percentage points less likely to be furloughed and 13 percentage points more likely to be unemployed than the non-BAME individuals.

$\mathrm{Hu}$ (2020) similarly analysed the UKHLS COVID-19 survey, examining intersecting ethnic and native-migrant inequalities in economic wellbeing in the context of the pandemic. Results indicate that BAME migrants in the UK were more likely to have experienced job loss, whilst BAME natives were less likely to enjoy employment protection such as furloughing, compared to the UK-born White British respondents. The UK-born White British respondents were also less likely to experience income loss and face increased financial hardship during the pandemic than BAME migrants (ibid). With Greater Manchester being home to over half of the foreign-born residents in the North West (Migration Observatory, 2014), and considering the COVID-19-induced challenges unique to migrants such as those with No Recourse to Public Funds (NRPF), it is important to consider the intersection of migrant status in discussions and interventions to mitigate the economic impact of the pandemic on ethnic minorities.

\subsubsection{Access to Benefits / Universal Credit}

Both Machin (2020) and Harris et al. (2020) explore the impact of additional funding, which was announced for the UK social security system and includes significant amendments to Universal Credit, disability, carers and sickness benefits. Machin (2020) argues that the response did not go far enough, arguing, like Millar (2020), that one of the most significant 
weaknesses in these measures is the failure to rectify the five-week delay for the first payment of Universal Credit.

Emerson et al. (2020) investigated the economic impacts of the lockdown using the UKHLS COVID-19 (ISER 2021) data, focussing their inquiry on employment and financial security for those with disabilities. Results indicate that working aged adults with a disability were more likely to be working reduced hours and experiencing higher levels of financial stress when compared to those without a disability. The Women's Budget Group (2020) find that of those who were out of work due to disability or were retired, over twice as many BAME women and men (42.5\% and $48.3 \%)$ reported that they had recently lost support from the government than White women and men (12.7\% and $20.6 \%)$. It is thus crucial that intersections of vulnerability are considered in policy response.

As shown in Table 1, Greater Manchester has seen vast increases in claimants for Universal Credit across all ten boroughs, with a surge of 90\% between March and July 2020. The largest increase in percentage points (as a proportion of residents aged 16-64) was noted for Oldham and Manchester, by 4.3 (to 9.4\%) and 4.2 (to 8.7\%) percent point increases over these four months. Meanwhile, in the UK, an increase from $3.0 \%$ to $6.3 \%$ was observed; whereas in Greater Manchester it was 4.3\% to 7.8\%. Further, Manchester, Oldham and Rochdale local authorities all have around $10 \%$ of the working age population claiming unemployment benefits, whilst the Greater Manchester average is $8 \%$, much higher than the national equivalent of 6.4\% (GMCA, 2020a).

Analysis of Universal Credit claimant count data in Manchester local authority between May and December 2020 reveals that four out of five LSOAs with the largest increases have majority BAME populations (see also the Case Study). This is true for both inand out-of-work claimants, suggesting that employment does not guarantee financial 
stability for these groups (Nomis, 2021). Qureshi et al. (2020), following Sandhu (2016), brought to light the intrinsic racial inequities in access to Universal Credit, including the twochild limit and barriers to application such as digital exclusion, further exacerbated by language barriers. Further protection is thus necessary for ethnic minority women who have been unduly affected by such constraints.

Table 1: Universal Credit count as a percentage of residents aged 16-64; March and July 2020, Greater Manchester boroughs.

\begin{tabular}{|l|c|c|c|c|c|c|c|c|c|c|}
\cline { 2 - 11 } \multicolumn{1}{c|}{} & Bolton & Bury & Manchester & Oldham & Rochdale & Salford & Stockport & Tameside & Trafford & Wigan \\
\hline March 2020 & 4.9 & 3.7 & $\mathbf{4 . 5}$ & 5.1 & 4.7 & 4.2 & 2.9 & 4.2 & 2.5 & 3.9 \\
\hline July 2020 & 8.4 & 7.1 & $\mathbf{8 . 7}$ & 9.4 & 8.6 & 8.1 & 6.0 & 7.9 & 5.3 & 6.9 \\
\hline $\begin{array}{l}\text { increase in } \\
\text { p.p. }\end{array}$ & 3.5 & 3.4 & 4.2 & 4.3 & 3.9 & 3.9 & 3.1 & 3.7 & 2.8 & 3.0 \\
\hline $\begin{array}{l}\text { \% of ethnic } \\
\text { minority in } \\
\text { total 16+ } \\
\text { population }\end{array}$ & 20.0 & 11.9 & 32.4 & 21.6 & 21.3 & 13.1 & 8.0 & 9.0 & 15.7 & 4.6 \\
\hline
\end{tabular}

Source: percentage of ethnic minority in the population based on Annual Population Survey and claimant count retrieved from Nomis database. 


\section{Case study: Benefits and Universal Credit claimants in Manchester}

In Figure 1, the counts of benefits claimants between January 2020 and 2021 in Lower Layer Super Output Areas (LSOAs) grouped by the percentage of BAME population residing in them are presented. We observe that the highest increases of the claimant counts have been recorded in the LSOAs with $40-80 \%$ of the BAME population. There is a positive association between the percentage of BAME in the LSOA and the count of benefit claimants.

Claimant counts by percentage of BAME population, January 2020-January 2021

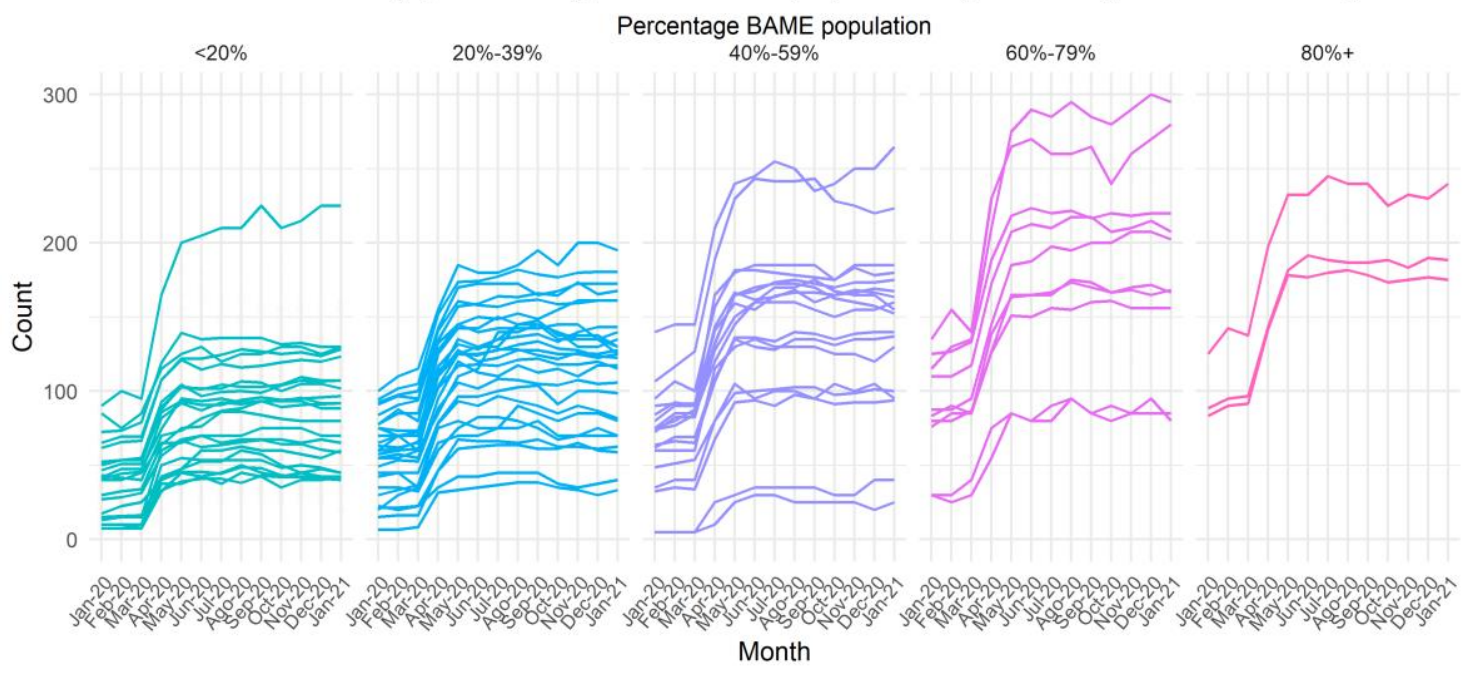

Figure 1: Claimant counts by percentage of BAME population, Manchester. Source: NOMIS Claimant Count data. There is a significant association between the number of claimants in LSOAs and the percentage of BAME population in each of them, that is, LSOA with a higher BAME population are more likely to have more claimants $\left(\chi^{\wedge} 2=40393080, d f=1124, p<0.001\right)$. 


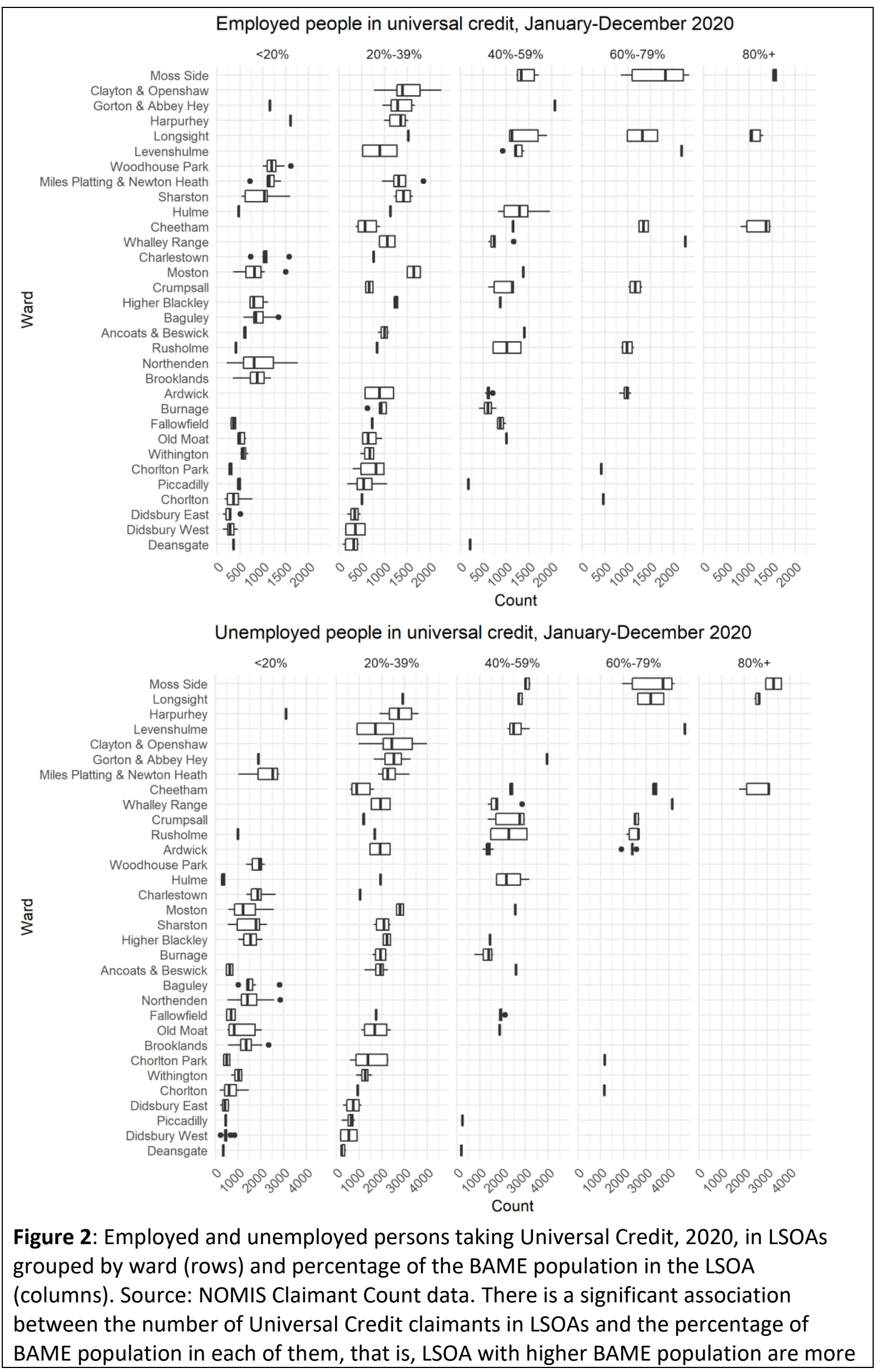


likely to have more claimants, for both employed $\left(\chi^{2}=2099280, \mathrm{df}=1124, \mathrm{p}<0.001\right)$ and unemployed $\left(\chi^{2}=3985320, \mathrm{df}=1124, \mathrm{p}<0.001\right)$.

In Figure 2, we observe that the association between the percentage of the BAME population within the LSOAs and the number of Universal Credit claimants, for both employed and unemployed. The wards with the highest number of claimants are consistent in both groups and include Moss Side, Longsight, Levenshulme, Harpurhey, Gorton \& Abbey Hey, Clayton \& Openshaw, and Miles Platting \& Newton Heath. The same wards have seen the highest rates of benefits claimants (Figure B.1 in Annex). The wards with the lowest counts of claimants include Deansgate, Didsbury West and East, Chorlton, Piccadilly and Withington. Figure B.2 in Annex presents maps of the percentage of BAME population in LSOAs (Panel a), total counts of benefits claimants (b), counts of Universal Credit claimants in employment (c), and counts of Universal Credit claimants unemployed (d), respectively.

\subsection{Care Workers and Parents}

Cominetti et al. (2020) provided an analysis of the social care workforce utilising the Labour Force Survey data, contextualising this within the COVID-19 pandemic. Their analysis showed that a disproportionate number of BAME workers were frontline care workers, whilst around half of frontline carers were paid less than the real Living Wage ${ }^{13}$.

Cheng et al. (2020) drew attention to the additional stress faced by working parents who, as a result of the school closures, had to spend additional time on childcare and home schooling. Their analysis showed that this burden is not equal across households of differing income and between men and women. In particular, working mothers were found to be experiencing worse financial and mental health outcomes. Further, Lee (2020) highlighted the lack of specific economic provision for families in the policy response to COVID-19,

\footnotetext{
${ }^{13}$ At the time of Cominetti et al's (2020) study this was $£ 10.75$ in London and $£ 9.30$ across the rest of the UK.
} 
finding that over two-thirds of parents reported having their work affected by COVID-19, compared to around a third of non-parents. That those of Bangladeshi and Pakistani ethnicity were more likely to have dependent children than those of other ethnicities (Platt and Warwick, 2020) is therefore of note, particularly given that working age adults with dependents primarily face employment and financial vulnerabilities (Mikolai et al. 2020). These difficulties are compounded by the fact that BAME individuals are less likely to have a partner in paid work whose income could buffer against a period of financial hardship (Platt and Warwick, 2020).

\subsection{Food Insecurity}

In April 2020, Loopstra (2020) identified that the pandemic had worsened food insecurity in the UK in three ways. Firstly, by increasing vulnerability to food insecurity for the economically vulnerable; secondly, by creating new vulnerability to food insecurity due to income losses; and finally, by creating new dimensions of food insecurity via people being unable to acquire food due to self-isolation and shielding. The report also finds that the BAME population has been at a significantly higher risk of food insecurity, especially arising from economic hardship.

Manchester's food banks saw unprecedented numbers of people in need of support, with Manchester South Central Food bank, which supports Hulme, Whalley Range, Old Trafford and Moss Side reporting a 250\% increase in demand for August, compared to the previous year (Maidment, 2020). Similar findings were reported by Graven et al. (2020) for the Bradford District. The authors further explained that some services were unable to cater to various dietary requirements and cultural and religious needs (such as halal food) in multiethnic and multi-faith areas. It has also been recommended that barriers to inclusion related to ethnicity and religion need to be better understood and addressed. 
Barker \& Russell (2020) discussed issues in the government's response to the food security crisis in Britain, including provisions for children who qualified for free school meals, and emergency food aid for older people with underlying health conditions. Both were provided food parcels that received public criticism for their nutritional content. In particular, for the older adults, many had comorbidities of diabetes, obesity and cardiovascular disease, with the food provided likely to exacerbate these issues. The authors also cited a heavy reliance on the voluntary sector to feed the food-insecure as a primary cause of the financial crisis in the charitable sector, compounded by reduced donations.

Power et al. (2020) highlighted the five-week wait for Universal Credit as a key factor in increases in food insecurity during the pandemic. The authors also drew light to the effect of austerity policies prior to the onset of the pandemic, illustrating that this increased food insecurity is occurring against a backdrop of growing inequality in access to food. Whilst the authors noted the impressive response of the government to the economic crisis brought by COVID-19, they argued that this underscored that it is the government's responsibility to protect population health and household incomes.

\subsection{Homelessness and Housing Insecurity}

Whilst the government's rapid response to provide additional funding to get rough sleepers off the streets was praised in a study of how COVID-19 has impacted on the homeless and those in temporary accommodation by Crankshaw et al. (2020), the authors urged the need for a focus on the sustainability of such methods. The summary drew particular attention to those in emergency accommodation with no recourse to public funds (NRPF) due to their immigration status, who might have lost work throughout the pandemic and who did not qualify for the Coronavirus Job Retention or Self-employment Income Support Schemes. There have been subsequent calls to remove the NRPF restrictions for the 
hundreds of migrants in Greater Manchester's localities (Greater Manchester Immigration Aid Unit, 2020). This sentiment has been backed by leaders including Mayor Andy Burnham in an open letter to the Home Office in December 2020, which urged the government to review the No Recourse policy in order to continue to protect people from rough sleeping (GMCA, 2020b).

Furthermore, it has been noted that asylum seekers rely heavily on services provided by charities (All Party Parliamentary Group on Refugees, 2017). Given reduced access to these services, with many moved online over the course of the pandemic, digital exclusion from such services constitutes another cause for concern.

Dickerson et al. (2020) conducted a survey during the first lockdown (10 April to 30 June 2020) to assess the experiences of families living in Bradford, a multi-ethnic and deprived area. A sample of 2,144 respondents has been obtained by means of emails, text and phone with a follow-up postal survey. 715 of respondents are White British, the rest are ethnic minorities with people of Pakistani heritage being the largest (47\%). Many families surveyed lived in poor quality or overcrowded housing. Insecure food and employment were also a common occurrence amongst those surveyed, particularly for the self-employed, furloughed, and unemployed.

\subsection{Other impacts}

As mentioned in the previous sections, the effects of the pandemic affect not only the economic outcomes of the ethnic minority groups, but also their mental health and wellbeing.

Several studies (Proto and Quintana-Domeque 2020; Pierce et al. 2020; Chandola et al. 2020) demonstrated the effects of the first lockdown on mental health in the UK. Proto and Quintana-Domeque (2020) focus on by the intersection of gender and ethnicity. The 
authors discover that BAME men, and both BAME and British White women experienced higher deteriorations in mental health than British White men. In further analyses, they ascertained that it is Bangladeshi, Indian and Pakistani respondents that are driving the gap between BAME and White men.

\section{Conclusions}

The onset of the COVID-19 pandemic and subsequent measures taken to mitigate its spread have occurred against a backdrop of inequity. As a result, ethnic minorities have faced worse labour market outcomes due to the pandemic and restrictions than White people across the

UK. The government's provisions have not included enough consideration for prior inequities in the labour market and the ways in which ethnic minority groups have been uniquely impacted by the pandemic because of these.

A recognition of the intersecting and multitudinous vulnerabilities faced by ethnic minority individuals in both Manchester and Greater Manchester is integral to producing an effective policy response. As Platt and Warwick (2020; 286) state, "There is no single narrative that can describe or account for the impacts of the current crisis on all minority groups". Pre-pandemic, these groups were already disadvantaged in numerous ways, facing lower levels of employment, and when employed more likely to work in insecure, low paid and undervalued jobs.

Nazroo et al. (2020) reached similar conclusions in their review for Greater London Authority. They found that there were substantial COVID-19-related inequalities, in terms of risk of infection, complications and mortality, as well as the negative economic, social and psychological consequences of Government policies to mitigate the health impacts of the pandemic. These inequalities related to ethnic minorities, people with disabilities, and women. While women have lower risk of mortality due to COVID-19, they experienced 
disproportionate economic, social and psychological impacts as a result of the coronavirus pandemic. Nazroo et al. (2020) also identified that it was the well-documented, prepandemic social and health inequalities that only deteriorated during the pandemic for those in most precarious situation.

\section{Recommendations}

Throughout this review, particularly negative labour market impacts have been noted for those of Bangladeshi and Pakistani ethnicity due to their being represented in high numbers in self-employment and/or in shutdown sectors, in conjunction with a higher prevalence of single-earner households and higher likelihood of having dependent children. The low levels of female employment for these groups are also of note. Pakistani people represent Greater Manchester's largest minority group (a third of whom lived in Manchester at the time of the last Census), and there are significant Bangladeshi populations across Greater Manchester, particularly in Manchester and Oldham, with Oldham having the largest Bangladeshi population outside of London (ONS, 2012). These groups require targeted interventions in order to aid their economic recovery.

Workers in shutdown sectors, the low paid, and those in insecure work (such as zerohours temporary contracts) have all faced disproportionate impacts on their economic wellbeing as a result of COVID-19 restrictions. Therefore, documented concentrations of ethnic minority workers in all these subsections of the workforce is a cause for concern. Policy response should also consider the disadvantages faced by insecure workers, aimed at creating better working conditions and more security for those employed in this type of work.

Further, upskilling Manchester's population, especially in terms of digital skills, should also be a priority. This is especially important for older population from Asian ethnic 
minority, who have been shown to have lower access to the ICT than the White population (see Sections 2.1.2 and 2.2.1). This lower access to the ICT also highlights a need to ensure this access by, for example, investment in the ICT infrastructure in areas with poor Internet coverage, and trainings on the use of Internet and online safety. Further, the upskilling could also target those in minority populations that are expected to be most disadvantaged by, e.g., language barriers when filling online forms, such as applications for Universal Credit (cf. Sandhu 2016).

The review also indicates a need for greater investment in affordable and social housing in order to prevent overcrowding, which has been identified before the pandemic struck as more prevalent in ethnic minority populations, especially Bangladeshi, Pakistani and Black African (ONS, 2020a; Lombard, 2021). It is relevant as the English Housing Survey (2021) also showed that in $2019 / 20,9 \%$ of houses in social renting sector were overcrowded, the highest levels since $1995 / 96$. The rate of the overcrowding was also highest amongst local authority tenants (11\%), as compared with housing association tenants (7\%) (idem). It is, therefore, likely, that the situation during lockdown might have exacerbated the overcrowding issue in Manchester, and that it disproportionately affected ethnic minority people, who are also more likely to rent social housing (see Section 1.2).

Alongside a focus on ethnic minorities, identifying ways to provide specific support for migrant populations, and those with no recourse to public funds, will also be important in the wake of the pandemic. As explained in Section 2.5, immigrants may more often found themselves in precarious situations because of job losses and not being able to seek allowances from Job Retention or Self-employment Income Support Schemes ('recourse to public funds'). This may be via an information campaign on access to benefits, social 
housing and other services, perhaps in native languages. Groups with no recourse to public funds are also in need of continued support in order to prevent homelessness.

Lastly, in the absence of timely data at lower geographical levels and disaggregated by ethnicity and/or migrant status, it is difficult to provide targeted aid in response to the pandemic. For example, Annual Population Survey data that contain some information disaggregated by Local Authorities and ethnicity, are released with around half-year delay. The data on Universal Credit claimants are reported publicly with one-month delay (and disaggregated by age and sex - though with values rounded to the nearest 5 for small areas), but come without any further breakdown by ethnicity. Scarcity of data by ethnicity/migrant status presents a significant gap that should be addressed in order to effectively mitigate the economic fallout of COVID-19 for those who most need it. 


\section{Bibliography}

Adams-Prassl, A., Boneva, T., Golin, M., Rauh, C., (2020) Inequality in the impact of the coronavirus shock: new survey evidence from the UK, [Online] Available at:

https://www.iza.org/publications/dp/13183/inequality-in-the-impact-of-the-coronavirusshock-evidence-from-real-time-surveys (Accessed 08/03/21)

All Party Parliamentary Group for Refugees (2017) Refugees Welcome? The Experience of New Refugees in the UK, The Refugee Council [Online] Available at:

https://www.refugeecouncil.org.uk/resources/refugees-welcome-the-experience-of-newrefugees-in-the-uk/ (Accessed 23/03/21)

Annual Population Survey (2019) Annual Population Survey - regional - ethnicity by industry. Retrieved from NOMIS:

https://www.nomisweb.co.uk/query/construct/summary.asp?mode=construct\&version=0\& dataset=180 (Accessed 25/04/21)

Annual Population Survey (2021) Annual Population Survey - regional - ethnicity by industry. Retrieved from NOMIS:

https://www.nomisweb.co.uk/query/construct/summary.asp?mode=construct\&version=0\& dataset=17 (Accessed 25/05/21)

Arthur, R. (2021). Studying the UK job market during the COVID-19 crisis with online job ads. Plos ONE, 16(5), e0251431.

Aum, S., Lee, S. Y. T., \& Shin, Y. (2020). COVID-19 doesn't need lockdowns to destroy jobs: The effect of local outbreaks in Korea. National Bureau of Economic Research Working Paper No. 27264. DOI: 10.3386/w27264.

Baker, S. R., Bloom, N., Davis, S. J., \& Terry, S. J. (2020). COVID-induced economic uncertainty. National Bureau of Economic Research Working Paper No. 26983. DOI: $10.3386 /$ w26983

Bambra, C., Smith, K. E., Garthwaite, K., Joyce, K. E., \& Hunter, D. J. (2011). A labour of Sisyphus? Public policy and health inequalities research from the Black and Acheson Reports to the Marmot Review. Journal of Epidemiology \& Community Health, 65(5), 399-406.

Bambra, C., Munford, L., Alexandros, A., Barr, B., Brown, H., Davies, H., Konstantinos, D., Mason, K., Pickett, K., Taylor, C., Taylor-Robinson, D., Wickham, S. (2020a) COVID-19 and the Northern Powerhouse, Northern Health Science Alliance [Online] Available at: https://www.thenhsa.co.uk/app/uploads/2020/11/NP-COVID-REPORT-101120-.pdf (Accessed 15/03/21)

Bambra, C., Riordan, R., Ford, J., \& Matthews, F. (2020b). The COVID-19 pandemic and health inequalities. J Epidemiol Community Health, 74(11), 964-968.

http://dx.doi.org/10.1136/jech-2020-214401 
Barker, M., \& Russell, J. (2020) Feeding the food insecure in Britain: learning from the 2020 COVID-19 crisis. [Online] Available at: https://link.springer.com/article/10.1007/s12571-02001080-5 (Accessed 15/03/21)

Bentley, G. R. (2020). Don't blame the BAME: Ethnic and structural inequalities in susceptibilities to COVID-19. American Journal of Human Biology, 32(5), e23478. https://doi.org/10.1002/ajhb.23478.

Benzeval, M., Burton, J., Crossley, T. F., Fisher, P., Jäckle, A., Low, H., \& Read, B. (3152020) The idiosyncratic impact of an aggregate shock: the distributional consequences of COVID19., [Online] Available at: https://papers.ssrn.com/sol3/papers.cfm?abstract_id=3615691 (Accessed 09/03/21)

Bhattacharjee, A., \& Lisauskaite, E. (2020). COVID-19 impacts on destitution in the UK. National Institute Economic Review, 253, [Online] Available at: https://www.cambridge.org/core/journals/national-institute-economicreview/article/abs/covid19-impacts-on-destitution-in-theuk/BD7DC079AE2E69887AF62B6543F75BAB (Accessed 18/03/21)

Blundell, R., Costa Dias, M., Joyce, R., \& Xu, X. (2020). COVID-19 and Inequalities. Fiscal Studies, 41(2), [Online] Available at: https://www.ucl.ac.uk/ uctp39a/Covid19 and Inequalities.pdf (Accessed 15/03/21)

Blundell, J., Machin., S. (2020) Self Employment in the COVID-19 crisis, Centre for Economic Performance, [Online] Available at: https://cep.Ise.ac.uk/pubs/download/cepcovid-19003.pdf (Accessed 09/03/21)

Breen, R., \& Ermisch, J. (2021) The distributional impact of COVID-19: Geographic variation in mortality in England, Demographic Research, [Online] Available at:

https://econpapers.repec.org/article/demdemres/v_3a44_3ay_3a2021_3ai_3a17.htm (Accessed 10/03/21)

Brewer, M., Tasseva, I., (2020) Did the UK Policy Response to COVID-19 Protect Household Incomes?, [Online] Available at:

https://papers.ssrn.com/sol3/papers.cfm?abstract_id=3628464 (Accessed 18/03/21)

Bronka, P., Collado, D., \& Richiardi, M. (2020). The COVID-19 crisis response helps the poor: The distributional and budgetary consequences of the UK lock-down. EUROMOD Working Paper. [Online] Available at: https://www.econstor.eu/handle/10419/228410 (Accessed $19 / 03 / 21)$

Chandola, T., Kumari, M., Booker, C. L., \& Benzeval, M. (2020). The mental health impact of COVID-19 and lockdown-related stressors among adults in the UK. Psychological medicine, 110. Doi: https://doi.org/10.1017/S0033291720005048.

Cheng, Z., Mendolia, S., Paloyo, A. R., Savage, D. A., \& Tani, M. (1212021) Working parents, financial insecurity, and childcare: mental health in the time of COVID-19 in the UK, [Online] 
Available at: https://link.springer.com/article/10.1007/s11150-020-09538-3 (Accessed $08 / 03 / 21)$

Citizen's Advice (2020) On the Edge: Insecure work in the pandemic [Online] Available at: https://www.citizensadvice.org.uk/about-us/our-work/policy/policy-research-topics/workpolicy-research-surveys-and-consultation-responses/work-policy-research/on-the-edgeinsecure-work-in-the-pandemic/ (Accessed 23/03/21)

Clift, A. K., Coupland, C. A., Keogh, R. H., Diaz-Ordaz, K., Williamson, E., Harrison, E. M., ... \& Hippisley-Cox, J. (2020). Living risk prediction algorithm (QCOVID) for risk of hospital admission and mortality from coronavirus 19 in adults: national derivation and validation cohort study. British Medical Journal, 371:m3731. Doi: https://doi.org/10.1136/bmj.m3731.

Cominetti, N., Gardiner, L., \& Kelly, G. (2020) What happens after the clapping finishes?. Resolution Foundation [Online] Available at:

https://www.resolutionfoundation.org/publications/what-happens-after-the-clappingfinishes/ (Accessed 08/03/21)

Crankshaw, B., Whitehead, C., Scanlon, K., (2972020) COVID and homelessness: what has been done? A position paper, [Online] Available at:

https://blogsmedia.Ise.ac.uk/blogs.dir/119/files/2020/07/Homelessness-Evidence-PositionPaper-final4510-1.pdf (Accessed 10/03/21)

Crawford, R., Davenport, A., Joyce, R., Levell, P., (2020) Household spending and coronavirus, Institute for Fiscal Studies [Online] Available at: https://www.ifs.org.uk/publications/14795 (Accessed 23/03/21)

Crossley, T. F., Fisher, P., \& Low, H. (2021) The heterogeneous and regressive consequences of COVID-19: Evidence from high quality panel data. Journal of Public Economics, [Online] Available at: https://www.sciencedirect.com/science/article/pii/S0047272720301985 (Accessed 23/03/21)

Department for Levelling Up, Housing and Communities (DLUHC) (2020) Local authority housing data. Department for Levelling Up, Housing and Communities and Ministry of Housing, Communities \& Local Government. 3 December 2020. [Online] https://www.gov.uk/government/collections/local-authority-housing-data. (Accessed $30 / 05 / 21)$

Dickerson, J., Kelly, B., Lockyer, B., Bridges, S., Cartwright, C., Willan, K., et al. (2020). Experiences of lockdown during the COVID-19 pandemic: descriptive findings from a survey of families in the Born in Bradford study. Wellcome Open Research, [Online] Available at: https://www.ncbi.nlm.nih.gov/pmc/articles/PMC7927208.1/ (Accessed 20/03/21)

DWP (2020) Employment and benefits support [Online] Available at: https://www.understandinguniversalcredit.gov.uk/employment-and-benefitssupport/already-claiming-benefits/ (Accessed 20/03/21) 
Elahi, F. (2017) Addressing Ethnic Inequality in the Greater Manchester Labour Market, Runnymede Trust [Online] Available at:

https://www.runnymedetrust.org/uploads/publications/IGAU-Briefing-7-Ethnicity.pdf (Accessed 08/03/21)

English Housing Survey (2021) English Housing Survey 2019-20. Ministry of Housing, Communities \& Local Government, Released 8 July 2021. [Online]

https://www.gov.uk/government/statistics/english-housing-survey-2019-to-2020-socialrented-sector (Accessed 30/07/21)

Etherington, D., Jones, M., (2017) Devolution, austerity and inclusive growth in Greater Manchester: Assessing Impacts and Developing Alternatives., CEEDR, Middlesex University [Online] Available at: https://www.mdx.ac.uk/_data/assets/pdf_file/0030/368373/GreaterManchester-Report.pdf (Accessed 09/03/21)

Emerson, E., Stancliffe, R., Hatton, C., Llewellyn, G., King, T., Totsika, V., Aitken, Z., Kavanagh, A. (2021) The impact of disability on employment and financial security following the outbreak of the 2020 COVID-19 pandemic in the UK, Journal of Public Health [Online] Available at: https://doi.org/10.1093/pubmed/fdaa270 (Accessed 11/03/21)

Financial Conduct Authority (2021) Financial Lives Survey Report, [Online] Available at: https://www.fca.org.uk/publication/research/financial-lives-survey-2020.pdf (Accessed $16 / 03 / 21)$

Fry, A., Littlejohns, T. J., Sudlow, C., Doherty, N., Adamska, L., Sprosen, T., ... \& Allen, N. E. (2017). Comparison of sociodemographic and health-related characteristics of UK Biobank participants with those of the general population. American journal of epidemiology, 186(9), 1026-1034. Doi: https://doi.org/10.1093/aje/kwx246.

Gardiner, L., Slaughter, H. (2020) The effects of the coronavirus crisis on workers, The Resolution Foundation [Online] Available at:

https://www.resolutionfoundation.org/app/uploads/2020/05/The-effect-of-thecoronavirus-crisis-on-workers.pdf (Accessed 10/03/21)

Gathergood, J., Gunzinger, F., Guttman-Kenney, B., Quispe-Torreblanca, E., \& Stewart, N. (2021). Levelling Down and the COVID-19 Lockdowns: Uneven Regional Recovery in UK Consumer Spending. COVID Economics, 67, [Online] Available at: https://papers.ssrn.com/sol3/papers.cfm?abstract id=3798679 (Accessed 18/03/21)

Goodwin, M. J., \& Heath, O. (2016). The 2016 referendum, Brexit and the left behind: An aggregate-level analysis of the result. The Political Quarterly, 87(3) [Online] Available at: https://onlinelibrary.wiley.com/doi/full/10.1111/1467923X.12285?casa token=HvAcsBfWvhwAAAAA\%3A56NpyTz0mnlJFCps7ZsdlyDjsag9cSJbnx71FnkXj15BSwUn2a6CoZBsLWjlo3MUxgj6gSr9yt9Fg (Accessed 09/03/21) 
GMCA (2020a) Greater Manchester Independent Prosperity Review: One Year On. Greater Manchester Combined Authority [Online] Available at: https://www.greatermanchesterca.gov.uk/media/3408/gmipr_one-year-on.pdf (Accessed 23/03/21)

GMCA (2020b) Greater Manchester leaders' open statement to the Home Office on asylum seeker evictions policy Greater Manchester Combined Authority [Online] Available at: https://www.greatermanchester-ca.gov.uk/news/greater-manchester-leaders-openstatement-to-the-home-office-on-asylum-seeker-evictions-policy/ (Accessed 23/03/21)

Graven, C., Power, M., Jones, S., Possingham, S., \& Bryant, M. (2020). Interim Report: The impact of COVID-19 on the provision of food aid in Bradford. UK Prevention Research Partnership \& University of York. https://www.bradfordresearch.nhs.uk/wpcontent/uploads/2020/11/Maria-Bryant-Updated-Interim-Report CFA.pdf (Accessed 17/04/2021)

Greater Manchester Immigration Aid Unit (2020) The impact of COVID-19 on people with a No Recourse to Public Funds condition. [Online] Available at: https://gmiau.org/the-impactof-covid-19-on-people-with-a-no-recourse-to-public-funds-condition/ (Accessed 23/03/21)

Hall, S., Mcintosh, K., Neitzert, E., Pottinger, L., Sandhu, K., Stephenson, M. A., ... \& Taylor, L. (2017). Intersecting inequalities: The impact of austerity on Black and Minority Ethnic women in the UK. Women's Budget Group, Runnymede Trust, Coventry Women's Voices and RECLAIM. 10 October 2017. [Online] https://barrowcadbury.org.uk/wpcontent/uploads/2017/10/Intersecting-Inequalities-October-2017-Full-Report.pdf (accessed 20/04/2021)

Harris, N., Fitzpatrick, C., Meers, J., \& Simpson, M. (2020). Coronavirus and social security entitlement in the UK, Journal of Social Security Law [Online] Available at:

https://papers.ssrn.com/sol3/papers.cfm?abstract id=3607312 (Accessed 20/03/21)

Hincks, S. (2017). Deprived neighbourhoods in transition: Divergent pathways of change in the Greater Manchester city-region. Urban Studies, 54(4), 1038-1061. DOI:

https://doi.org/10.1177/0042098015619142.

HMRC (2020) Self Employment Income Support Scheme: service availability and issues [Online] Available at: https://www.gov.uk/government/publications/self-employmentincome-support-scheme-service-availability-and-issues (Accessed 25/03/21)

HM Treasury (2020) The Chancellor Rishi Sunak provides an updated statement on coronavirus (Online) Available at: https://www.gov.uk/government/speeches/thechancellor-rishi-sunak-provides-an-updated-statement-on-coronavirus (Accessed 25/08/2020)

$\mathrm{Hu}, \mathrm{Y}$. (2020). Intersecting ethnic and native-migrant inequalities in the economic impact of the COVID-19 pandemic in the UK. Research in Social Stratification and Mobility, 68, 100528. [Online] Available at:

https://www.sciencedirect.com/science/article/pii/S0276562420300640?casa token=2k KH 
Nk7sNwAAAAA:NN4wV9NOHvfJMDoZMipdQ9m1qDwjnu5tFz6BfcxpiUVGox|4x8TLIRCZYoED gMAoOIXFS26k (Accessed 08/03/21)

Hughes, C., \& Lupton, R. (2018). Understanding Changes in Greater Manchester's 'Deprived' Neighbourhoods 2004-2015 Using a Typology of Residential Mobility. Joseph Rowntree Foundation [Online] Available at:

http://hummedia.manchester.ac.uk/institutes/mui/igau/igau-residential-movestypology.pdf (Accessed 09/03/21)

Jeffery, B., Devine, D., Thomas, P. (2018) There's Nothing': Unemployment, Attitudes to Work and Punitive Welfare Reform in Post-Crash Salford, Sociological research online, 23(4) [Online] Available at: https://journals.sagepub.com/doi/full/10.1177/1360780418787521 (Accessed 11/03/21)

Jivraj, S. (2013) Geographies of diversity in Manchester, Centre on Dynamics of Ethnicity [Online] Available at:

https://hummedia.manchester.ac.uk/institutes/code/briefings/localdynamicsofdiversity/geo graphies-of-diversity-in-manchester.pdf (Accessed 08/03/21)

Khan, J. M., \& Beevers, D. G. (2005). Management of hypertension in ethnic minorities. Heart, 91(8), 1105-1109. http://dx.doi.org/10.1136/hrt.2004.044560.

Kennedy, S, \& Ferguson, D. (2021) Coronavirus: Test \& Trace Support Payments. House of Commons Library Briefing Paper, Number CBP-9015, 12 March 2021.

https://commonslibrary.parliament.uk/research-briefings/cbp-9015/ (accessed 15/04/2021)

Khunti K., Routen A., Pareek M., Treweek S., Platt L. (2020) The language of ethnicity. British Medical Journal 371:m4493 doi: http://doi.org/10.1136/bmj.m4493

Lawrence, D., (2020) An avoidable crisis. the disproportionate impact of COVID-19 on black, Asian and minority ethnic communities. A review by Baroness Doreen Lawrence. [Online] Available at: www.lawrencereview.co.uk. (Accessed 15/03/21)

Lee, T. (2020) Families Hit Harder Because Nothing For Children in COVID-19 Response, Child Poverty Action Group [Online] Available at: https://cpag.org.uk/news-blogs/newslistings/families-hit-harder-because-nothing-children-covid-19response\#: :text=There\%20was\%20nothing\%20family\%20focused,was\%20nothing\%20speci fically\%20for\%20children.\&text=62\%25\%20of\%20parents\%20reported $\% 20$ having,35\%25\%2 0of\%20non\%2Dparents. (Accessed 09/03/21)

Lombard, M. (2021). The experience of precarity: low-paid economic migrants' housing in Manchester. Housing Studies, 1-19. [Online] Available at:

https://www.tandfonline.com/doi/full/10.1080/02673037.2021.1882663?casa_token=87C2I yID6EwAAAAA\%3ATnuvAQdXSn1JvuEdTVxmAYGyxI9kfNS7YYbIARhWpIG8G95sV0ey0YuCKJYi c7wxDftarxHqqwA (Accessed 09/03/21) 
Loopstra, R. (1442020) Vulnerability to food insecurity since the COVID-19 lockdown, The Food Foundation [Online] Available at: https://foodfoundation.org.uk/wpcontent/uploads/2020/04/Report COVID19FoodInsecurity-final.pdf (Accessed 10/03/21)

Lupton, R., Rafferty, A. \& Hughes, C. (2016) Inclusive Growth: Opportunities and Challenges for Greater Manchester. University of Manchester, Manchester. [Online] Available at: http://www.cities.manchester.ac.uk/medialibrary/igau/IGAU-report-2016-FINAL.pdf (Accessed 10/03/21)

Lymperopoulou K, Finney N. (2017) Socio-spatial factors associated with ethnic inequalities in dictricts of England and Wales, 2001-2011, Urban Studies, 54(11) [Online] Available at: https://journals.sagepub.com/doi/pdf/10.1177/0042098016653725 (Accessed 08/03/21)

Maidment, A., (2020) What the pandemic has taught Manchester's food banks in preparing for winter. Manchester Evening News. [Online] Available at:

https://www.manchestereveningnews.co.uk/news/greater-manchester-news/food-bankswinter-pandemic-demand-18956451 (Accessed 23/03/21)

Maital, S., \& Barzani, E. (2020). The global economic impact of COVID-19: A summary of research. Samuel Neaman Institute for National Policy Research, 2020, 1-12. https://www.neaman.org.il/EN/Files/Global\%20Economic\%20Impact\%20of\%20COVID19 20200322163553.399.pdf (Accessed 16/04/2021).

Marmot, M. (2020). Health equity in England: the Marmot review 10 years on. Bmj, 368. doi: https://doi.org/10.1136/bmj.m693.

Marszalek, K., Peytrignet, S., (2020). Understanding the needs of those most clinically vulnerable to COVID-19. The Health Foundation. [Online] Available at:

https://www.health.org.uk/news-and-comment/charts-and-infographics/understandingthe-needs-and-experiences-of-those-most-clinic (Accessed 11/03/21)

Mayhew, K., \& Anand, P. (2020) COVID-19 and the UK Labour Market, Oxford University Press [Online] Available at: https://covidaba.com/wp-content/uploads/2020/06/COVID-19AND-THE-UK-LABOUR-MARKET.pdf (Accessed 15/03/21)

McCann, P. (2016) The UK regional-national economic problem: Geography, globalisation and governance., London: Routledge

McCann, P. (2020). Perceptions of regional inequality and the geography of discontent: Insights from the UK. Regional Studies, 54(2), 256-267.

https://www.tandfonline.com/doi/full/10.1080/00343404.2019.1619928 (Accessed 08/03/21)

Machin, R. (2021) COVID-19 and the temporary transformation of the UK social security system, [Online] Available at: https://doi.org/10.1177/0261018320986793 (Accessed $10 / 03 / 21)$ 
The Migration Observatory (2014) Changes to the migrant population of the North West of England 2001-2011 [Online] Available at:

https://migrationobservatory.ox.ac.uk/press/changes-to-the-migrant-population-of-thenorth-west-of-england-2001-2011/ (Accessed 23/03/21)

Mikolai, J., Keenan, K., \& Kulu, H. (2020) Intersecting household-level health and socioeconomic vulnerabilities and the COVID-19 crisis: An analysis from the UK., SSM-Population Health [Online] Available at:

https://www.sciencedirect.com/science/article/pii/S2352827320302652 (Accessed $18 / 03 / 21)$

Ministry of Housing, Communities and Local Government. (2020) Renting social housing, English Housing Survey 2016-2018. Released 4 February 2020 [Online]

https://www.ethnicity-facts-figures.service.gov.uk/housing/social-housing/renting-from-alocal-authority-or-housing-association-social-housing/latest (Accessed 30/04/21)

Millar, J (2020) Social security and COVID-19: Exposing the limits of social protection? [Online] Available at: http://blogs.bath.ac.uk/iprblog/2020/04/15/social-security-and-covid19-exposing-the-limits-of-social-protection/ (Accessed 22/03/21)

Milne, A. (2020). UK under fire for suggesting coronavirus 'great leveller'. London: Thomas Reuters Foundation [Online] Available at: https://uk.reuters.com/article/us-healthcoronavirus-leveller-trfn/uk-under-fire-for-suggesting-coronavirus-great-levelleridUSKCN21R30P (Accessed 15/03/21)

Mogaji, E. (2020) Financial Vulnerability During a Pandemic: Insights for Coronavirus Disease (COVID-19), [Online] Available at:

https://papers.ssrn.com/sol3/papers.cfm?abstract id=3564702 (Accessed 15/03/21)

Moorthy, A., \& Sankar, T. K. (2020) Emerging public health challenge in UK: perception and belief on increased COVID19 death among BAME healthcare workers., Journal of Public Health, 42(3) [Online] Available at:

https://academic.oup.com/ipubhealth/article/42/3/486/5866648 (Accessed 15/03/21)

Nazroo, J. Y. (2003). The structuring of ethnic inequalities in health: economic position, racial discrimination, and racism. American Journal of Public Health, 93(2), 277-284.

Nazroo, J., Murray, K., Taylor, H., Bécares, L., Field, Y., Kapadia, D., \& Rolston, Y. (2020). Rapid Evidence Review: Inequalities in relation to COVID-19 and their effects on London. University of Manchester, The Ubele Initiative, University of Sussex. [Online] https://data.london.gov.uk/dataset/rapid-evidence-review-inequalities-in-relation-to-covid19-and-their-effects-on-london (Accessed 21/04/2021)

Nazroo, J., \& Becares, L. (2020). Evidence for ethnic inequalities in mortality related to COVID-19 infections: findings from an ecological analysis of England. BMJ open, 10(12), e041750. 
New Economy (2017) Greater Manchester Skills Analysis 2016-2017 [Online] Available at: https://www.greatermanchester-ca.gov.uk/media/2020/skills-analysis-2016-17-mastercopyfinal-draft-14032017.pdf (Accessed 17/03/21)

Nicola ,M., Alsafi, Z., Sohrabi, C., Kerwan, A. (2020) The socio-economic implications of the coronavirus pandemic: a review, International Journal of Surgery, 78 [Online] doi: https://doi.org/10.1016/j.ijsu.2020.04.018.

Nomis (2021) Labour Market Profile - Greater Manchester [Online] Available at: https://www.nomisweb.co.uk/reports/Imp/lep/1925185547/report.aspx (Accessed 09/03/21)

ONS (2012) 2011 Census: Ethnic group, local authorities in England, [Online] Available at: https://www.nomisweb.co.uk/census/2011/ks201ew (Accessed 10/03/21)

ONS. (2019) Exploring the UK's digital divide. Released 4 March 2019. [Online] Available at: https://www.ons.gov.uk/peoplepopulationandcommunity/householdcharacteristics/homein ternetandsocialmediausage/articles/exploringtheuksdigitaldivide/2019-03-04\#the-scale-ofdigital-exclusion-in-the-uk (accessed 29/05/21)

ONS. (2020a). Overcrowded Housing. [Online] Available at: https://www.ethnicity-factsfigures.service.gov.uk/housing/housing-conditions/overcrowded-households/latest\#byethnicity-and-area (Accessed 15/03/21)

ONS. (2020b) Coronavirus and Homeworking in the UK [Online] Available at: https://www.ons.gov.uk/employmentandlabourmarket/peopleinwork/employmentandempl oyeetypes/bulletins/coronavirusandhomeworkingintheuk/april2020 (Accessed 23/03/21)

ONS. (2020c) Youth Unemployment, January to March 2019 to October to December 2020 [Online] Available at:

https://www.ons.gov.uk/employmentandlabourmarket/peoplenotinwork/unemployment/a dhocs/12960youthunemploymentjanuarytomarch2019tooctobertodecember2020 (Accessed $18 / 04 / 21)$

ONS. (2020d) Regional gross disposable household income: local authorities by NUTS1 region. Released 4 June 2020. [Online] Available at:

https://www.ons.gov.uk/economy/regionalaccounts/grossdisposablehouseholdincome/data sets/regionalgrossdisposablehouseholdincomebylocalauthoritiesbynuts1region (Accessed 30/04/21)

ONS. (2020e) Updating ethnic contrasts in deaths involving the coronavirus (COVID-19), England, 24 January 2020 to 31 March 2021. Dataset Released 26 May 2021. [Online] https://www.ons.gov.uk/peoplepopulationandcommunity/birthsdeathsandmarriages/death s/datasets/updatingethniccontrastsindeathsinvolvingthecoronaviruscovid19england (Accessed 29/05/21) 
ONS. (2021) Effects of taxes and benefits on UK household income: financial year ending 2020. Office for National Statistics. Released 28 May 2021. [Online]

https://www.ons.gov.uk/peoplepopulationandcommunity/personalandhouseholdfinances/i ncomeandwealth/bulletins/theeffectsoftaxesandbenefitsonhouseholdincome/financialyeare nding2020 (Accessed 29/05/21)

Patel, J. A., Nielsen, F. B. H., Badiani, A. A., Assi, S., Unadkat, V. A., Patel, B., Ravindrane, R., \& Wardle, H. (2020) Poverty, inequality and COVID-19: the forgotten vulnerable., Journal of Public Health. 183. [Online] Available at:

https://www.ncbi.nlm.nih.gov/pmc/articles/PMC7221360/ (Accessed 16/03/21)

Patel, P., Hiam, L., Sowemimo, A., Devakumar, D., McKee, M., (2020). Ethnicity and covid-19, The British Medical Journal [Online] Available at:

https://www.bmj.com/content/369/bmj.m2282.full (Accessed 08/03/21)

Penney, B. (2019) The English Indices of Deprivation 2019 (IoD2019). Ministry of Housing, Communities \& Local Government. [Online] Available at:

https://assets.publishing.service.gov.uk/government/uploads/system/uploads/attachment_ data/file/835115/IoD2019_Statistical_Release.pdf (Accessed 15/03/21)

Platt, L., \& Warwick, R. (2020). COVID-19 and ethnic inequalities in England and Wales. Fiscal Studies, 41(2), [Online] Available at: https://doi.org/10.1111/1475-5890.12228 (Accessed $16 / 03 / 21)$

Power, M., Doherty, B., Pybus, K., \& Pickett, K. (2020) How COVID-19 has exposed inequalities in the UK food system: The case of UK food and poverty, Emerald Open Research [Online] Available at: https://www.ncbi.nlm.nih.gov/pmc/articles/PMC7219559/ (Accessed $16 / 03 / 21)$

Prats-Uribe, A., Paredes, R., \& Prieto-Alhambra, D. (2020) Ethnicity, comorbidity, socioeconomic status, and their associations with COVID-19 infection in England: a cohort analysis of UK Biobank data, [Online] Available at:

https://www.medrxiv.org/content/medrxiv/early/2020/05/13/2020.05.06.20092676.full.pdf (Accessed 08/03/21)

Proto, E., \& Quintana-Domeque, C. (2021). COVID-19 and mental health deterioration by ethnicity and gender in the UK. PloS one, 16(1), e0244419. Doi:

https://doi.org/10.1371/journal.pone.0244419.

Public Health England. (2020a). Disparities in the risk and outcomes of COVID-19. PHE. [Online] Available at:

https://assets.publishing.service.gov.uk/government/uploads/system/uploads/attachment data/file/908434/Disparities in the risk and outcomes of COVID August 2020 update.p df (Accessed 15/03/21)

Public Health England. (2020b). Analysis of the relationship between pre-existing health conditions, ethnicity and COVID-19. PHE December 2020. [Online] Available at: 
https://assets.publishing.service.gov.uk/government/uploads/system/uploads/attachment_data/ file/942091/Summary_report_ethnicity_and_comorbidity.pdf (Accessed 15/04/21)

Quilter-Pinner, H., Thomas, C., Harvey, R., Wastell, D. (2020) COVID-19: One in five healthcare workers could quit after pandemic unless urgent government action is taken, IPPR warns, Institute of Public Policy Research, [Online] Available at: https://www.ippr.org/newsand-media/press-releases/covid-19-one-in-five-healthcare-workers-could-quit-afterpandemic-unless-urgent-government-action-is-taken-ippr-warns (Accessed 18/03/21)

Qureshi, K, Kasstan, B, Meer, N, Hill, S (2020) Submission of evidence on the disproportionate impact of COVID-19, and the UK government response, on ethnic minorities in the UK. Available at: https://ghpu.sps.ed.ac.uk/wp-content/uploads/2020/04/Qureshi-KasstanMeer-Hill working-paper COVID19-ethnic-minorities 240420.pdf (Accessed 23/03/21)

Pierce, M., Hope, H., Ford, T., Hatch, S., Hotopf, M., John, A., ... \& Abel, K. M. (2020). Mental health before and during the COVID-19 pandemic: a longitudinal probability sample survey of the UK population. The Lancet Psychiatry. (Online) doi: https://doi.org/10.1016/S22150366(20)30308-4

Razai, M. S., Kankam, H. K., Majeed, A., Esmail, A., \& Williams, D. R. (2021). Mitigating ethnic disparities in covid-19 and beyond. The British Medical Journal, 372. [Online] Available at: https://www.bmj.com/content/372/bmj.m4921 (Accessed 11/03/21)

Reuschke, D., Price, V., Henley, A., \& Daniel, E. (2020) Changes in UK Self-employment in April-June 2020., [Online] Available at: http://workfutures.southampton.ac.uk/blog/changesin-uk-self-employment-by-regions-and-

gender/\#: :text=Almost\%20half\%20of\%20the\%20total,47\%25\%20or\%20109\%2C000\%20peo ple).\&text=The\%20dramatic\%20reduction\%20in\%20self,2020\%20compared\%20to\%20previ ous\%20years. (Accessed 10/03/21)

Royal College of Nursing (2020) Second Personal Protective Equipment Survey of UK Nursing Staff Report: Use and availability of PPE during the COVID-19 pandemic, [Online] Available at: https://www.rcn.org.uk/professional-development/publications/rcn-second-ppe-surveycovid-19-pub009269 (Accessed 15/03/21)

Sandhu, K. (2016). Universal Credit and impact on Black and minority ethnic communities. Better Housing Briefing 27, Racial Equality Foundation. [Online] Available at: https://raceequalityfoundation.org.uk/wpcontent/uploads/2017/11/Better-Housing-27UniversalCredit.pdf (Accessed 20/04/21)

Sandhu, K., \& Stephenson, M. A. (2015) Layers of inequality-a human rights and equality impact assessment of the public spending cuts on Black, Asian and minority ethnic women in Coventry. Feminist Review, 109(1), 169-179.

Sá, F. (2020) Socioeconomic Determinants of COVID-19 Infections and Mortality: Evidence from England and Wales, SSRN. [Online] Available at:

https://papers.ssrn.com/sol3/papers.cfm?abstract_id=3612850 (Accessed 10/03/21) 
Sensier, M., \& Devine, F. (2020). Understanding regional economic performance and resilience in the UK: trends since the global financial crisis. National Institute Economic Review, 253 [Online] Available at: https://www.cambridge.org/core/journals/nationalinstitute-economic-review/article/understanding-regional-economic-performance-andresilience-in-the-uk-trends-since-the-global-financialcrisis/EF4CD50D4F1975293BA145A7C75B9A18 (Accessed 15/03/21)

Susskind, D., \& Vines, D. (2020) The economics of the COVID-19 pandemic: an assessment, [Online] Available at:

https://academic.oup.com/oxrep/article/36/Supplement_1/S1/5899022?login=true (Accessed 16/03/21)

Townsend, P., \& Davidson, N. (1982). The black report. In Inequalities in Health: The Black Report. Penguin Books, Harmondsworth.

THINK (2020) Planning for the Economic Recovery: Work and Skills - June 2020. (Accessed Via Manchester City Council).

Timms, D., Jackson, D., Emmerich, M. (2020) Why has Manchester been hit so hard by the second wave of coronavirus? Economics Observatory [Online] Available at:

https://www.economicsobservatory.com/why-has-manchester-been-hit-so-hard-secondwave-coronavirus (Accessed 19/03/21)

Tubadji, A., Webber, D. J., \& Boy, F. A. (2020) Cultural and economic discrimination by the great leveller: the COVID-19 pandemic in the UK., CEPR. [Online] Available at:

https://voxeu.org/article/cultural-and-economic-discrimination-great-leveller (Accessed 19/03/21)

TUC (2017) Living on the edge, The Trades Union Congress [Online] Available at: https://www.tuc.org.uk/research-analysis/reports/living-edge-0 (Accessed 21/03/21)

ISER - University of Essex, Institute for Social and Economic Research (2021). Understanding Society: COVID-19 Study, 2020-2021. [data collection]. 8th Edition. UK Data Service. SN: 8644, http://doi.org/10.5255/UKDA-SN-8644-8.

Williamson, E. J., Walker, A. J., Bhaskaran, K., Bacon, S., Bates, C., Morton, C. E., ... \& Goldacre, B. (2020). Factors associated with COVID-19-related death using OpenSAFELY. Nature, 584(7821), 430-436. DOI: https://doi.org/10.1038/s41586-020-2521-4.

Witteveen, D. (2020). Sociodemographic inequality in exposure to COVID-19-induced economic hardship in the United Kingdom. Research in social stratification and mobility, 69, 100551. DOI: https://doi.org/10.1016/i.rssm.2020.100551

Womens Budget Group (2020) New data reveals "crisis of support" for BAME women [Online] Available at: https://wbg.org.uk/media/new-data-reveals-crisis-of-support-forbame-women/ 
Yasenov, V. (2020) Who can work from home?, Institute of Labor Economics [Online] Available at: https://www.iza.org/publications/dp/13197/who-can-work-from-home (Accessed 11/03/21)

Yue, W., \& Cowling, M. (2021). The Covid-19 lockdown in the United Kingdom and subjective well-being: Have the self-employed suffered more due to hours and income reductions?. International Small Business Journal, 39(2), 93-108. DOI:

https://doi.org/10.1177/0266242620986763. 


\section{Annex}

\section{A Data Sources}

This section describes the datasets that are currently available and most relevant to research on this topic. They constitute economic data that can be broken down into ethnic groups and enable data analysis mostly at a Local Authority level. Some of these datasets contain questions directly related to COVID-19. Others do not have specific questions regarding COVID-19 but their application in the period before the pandemic and during it allows the analysis of the differences between both points in time. The data sources are summarised in Table A.1.

The Annual Population Survey (APS) is an annual survey with the largest sample in the UK $(320,000 \text { individuals and } 150,000 \text { households })^{14}$. This survey covers topics on individual demographics including ethnicity, labour market status, and work characteristics (such as employment by occupation, sector, qualification level, self-employment, unemployment by qualification level, length of time spent in unemployment, economic inactivity and average hourly pay). This survey has specific person and household datasets that enable analysis at a local authority level. However, the sample sizes render the confidence intervals relatively wide for meaningful analyses of, for example, unemployment rates, over time at small geographies. APS uses the ethnic categories from the 2011 Census with some modifications when displaying results. This survey aggregates Black, Mixed and Other ethnic groups into single group. It also groups Indian, Pakistani and Bangladeshi in a unique category, separate from other Asian ethnic groups. By contrast, it shows results ies/labourforcesurveyuserguidance, Volume 10. 
separately for the White British and Other White. The most recent data are from September 2020, with the next release scheduled for 20 April 2021.

The Labour Force Survey (LFS) has the same core questions as the APS. However, the LFS sample size is smaller than the APS sample $(95,000$ persons and 39,000 households). Despite this, the LFS also allows analysis at a local level (LA). The LFS provides annual information on economic activity, occupation, qualification and hours worked. LFS information can be broken down by - amongst other individual characteristics - ethnicity. There are LFS weekly and monthly estimates, but they are not at a local level.

Since March 2020, the ONS has implemented the Labour Market Survey (LMS), for which samples are drawn from the Postcode Address File. This survey is applied quarterly and aims to test a mixed-mode design for a household survey ${ }^{15}$. Based on the LMS, the ONS released a report Coronavirus and Homeworking in the UK, which looks at homeworking patterns in the UK disaggregated by sex, age, region and ethnicity.

Understanding Society: the UK Household Longitudinal Study (UKHLS) is a large national probability-based household survey that has been collecting and publishing data annually since 2009. Since April 2020, this study included questions regarding the impact of the pandemic on participants' welfare, in domains such as employment, finances, financial security and coronavirus illness. Six waves have been collected during 2020 (in April, May, June, July, September and November). Data from the seventh COVID-19 wave, collected in January 2021, will be released at the end of March 2021. Data is available at a LSOA level (within secure access) and can be disaggregated by ethnicity.

15

https://www.ons.gov.uk/employmentandlabourmarket/peopleinwork/employmentandemployeetypes/methodolog ies/labourmarketsurveyresearchandresultsoverview\#what-you-need-to-know-about-this-release. 
Amongst the statistics that the UKHLS enables to produce is the Income Dynamics Statistics reported by the Department for Work and Pensions (DWP). This specific dataset is about persistent low income and changes in income of individuals and households. These data can be disaggregated by local authority level and ethnicity.

The Opinions and Lifestyle Survey (OPN) measures the impact of COVID-19 on people's work for around 4,000-4,500 individuals in Great Britain ${ }^{16}$. The survey also includes questions related to taxation, food safety, and health. The survey has been collected weekly since 20 March 2020 and its last release was on 20 March 2021. Data can be obtained by local authorities and ethnicity.

The Family Resources Survey is an annual survey, with results published by the Department for Work and Pensions. This survey includes economic variables (e.g. household income, state support, and sources of household income) broken down by ethnicity. Some of the variables can be found by local authority level (for example, State support). No questions specific to COVID-19 were included in the latest release (25 March 2021). This last release corresponds to the financial year April 2019 to April 2020.

The Business Insights and Conditions Survey (BICS) provides information on financial performance, workforce, prices, trade, and business resilience. This survey has been collected fortnightly for 26 waves. Since the seventh wave, the methodology of this survey has changed. Data from wave 7 (2 July 2020) to wave 26 (25 March 2021) are now available ${ }^{17}$. Experimental weighted regional and local estimates were calculated from the

16

https://www.ons.gov.uk/peoplepopulationandcommunity/healthandsocialcare/healthandlifeexpectancies/method ologies/opinionsandlifestylesurveyqmi

https://www.ons.gov.uk/economy/economicoutputandproductivity/output/datasets/businessinsightsandimpactont heukeconomy 
BICS. Based on these estimates, the ONS released a report on the Business insights and Impact on the Subnational UK Economy from 21 September 2020 to 10 January $2021^{18}$. In addition, unweighted estimates were obtained from BICS, conforming the Business Impact of COVID-19 Survey (BICS) results. These results were produced fortnightly from 9 March 2020 to 1 November 2020. This COVID-19-specific survey was discontinued ${ }^{19}$. Given that the unit of analysis in BICS is businesses, this dataset does not account for ethnicity.

The Annual Survey of Hours and Earnings (ASHE) is an annual survey that collects information on weekly pay, basic pay, overtime pay, gross hourly pay, gross annual pay, annual incentive, total paid hours, and basic paid hours. Since 21 April 2021, this survey was modified to account for the Coronavirus Job Retention Scheme ("furloughing"). The modifications included asking whether the employee was furloughed fully or partly and asking employers for payments due to furloughs. These data allow the data analysis at a local authority level, but it only disaggregates information by sex. The latest realise was on 05 November 2020, with the next one scheduled for November 2021.

Additionally, some data are produced by the Department for Work and Pensions (DWP) that enable the analysis of the economic impacts of COVID on the BAME population at a local level. One of the most important datasets is the Claimant Count and Flow data. These data provide monthly information on the number of people claiming Jobseeker's Allowance (JSA) and those claiming Universal Credit (UC) (such as those claiming benefits

18

https://www.ons.gov.uk/economy/economicoutputandproductivity/output/datasets/businessinsightsandimpactont hesubnationalukeconomy

https://www.ons.gov.uk/economy/economicoutputandproductivity/output/datasets/businessimpactofcovid19surv eybicsresults 
due to being unemployed $)^{20}$. The DWP collects these data by individual characteristics (e.g. age, duration, ethnicity, occupation) and has georeferenced data by using postcode or output areas. The last aspect enables the analysis at a local level. The next release of these data will be on 20 April 2021.

The English Longitudinal Study of Ageing (ELSA) collects information on individuals aged over 50 years old. Due to the current pandemic, ELSA has collected data on the effects of COVID on older people, focusing on the financial consequences of the coronavirus pandemic. There have been two collections for the COVID-19 study (on 26 July 2020 and 20 December 2020).

Table A.1: A selection of data sources containing information on COVID-19 economic impacts. Note: An updated list of data sources related to COVID-19 are available at the UK Data Service: https://www.ukdataservice.ac.uk/get-data/themes/covid-19.aspx; official UK Government data are available at https://coronavirus.data.gov.uk/.

\begin{tabular}{|c|c|c|c|c|c|}
\hline Data & Custodian & $\begin{array}{l}\text { Where } \\
\text { Available }\end{array}$ & Variables of Interest & Dates & Link \\
\hline $\begin{array}{l}\text { Business } \\
\text { Impacts of } \\
\text { COVID-19 } \\
\text { Survey }\end{array}$ & ONS & ONS & $\begin{array}{l}\text { Economic Impacts of } \\
\text { COVID }\end{array}$ & $\begin{array}{l}\text { March - } \\
\text { November } \\
2020\end{array}$ & https://www.ons.gov.uk/economy... \\
\hline $\begin{array}{l}\text { Claimant } \\
\text { Count Data }\end{array}$ & NOMIS & NOMIS & $\begin{array}{l}\text { Unemployment, Benefits, } \\
\text { Geographies }\end{array}$ & Since 1986 & https://www.nomisweb.co.uk/querr/select/... \\
\hline $\begin{array}{l}\text { Coronavirus } \\
\text { and } \\
\text { Homeworking } \\
\text { in the UK }\end{array}$ & ONS & $\begin{array}{l}\text { UK Data } \\
\text { Service }\end{array}$ & $\begin{array}{l}\text { Region, Ethnic Minority } \\
\text { Indicators }\end{array}$ & Apr-20 & https:///www.ons.gov.uk//employmentandlabourmarket/... \\
\hline $\begin{array}{l}\text { COVID-19 } \\
\text { Vaccinations } \\
\text { (Weekly) }\end{array}$ & NHS & NHS & $\begin{array}{l}\text { Age, Dose, Region, } \\
\text { Ethnicity, MSOA, Care } \\
\text { Homes, NHS workers, } \\
\text { Clinically Extremely } \\
\text { Vulnerable }\end{array}$ & $\begin{array}{l}\text { Weekly } \\
\text { from } 11 \\
\text { Jan } 2021\end{array}$ & https://www.england.nhs.uk/statistics/... \\
\hline
\end{tabular}

20

https://www.ons.gov.uk/employmentandlabourmarket/peopleinwork/employmentandemployeetypes/methodolog ies/claimantcountqmi\#: :text=The $\% 20$ Claimant $\% 20$ Count $\% 20$ is $\% 20$ a,data $\% 20$ from $\% 20$ the $\% 20$ benefits $\% 20$ sys tem.\&text=The $\% 20$ Claimant $\% 20$ Count $\% 20$ has $\% 20$ undergone,Credit $\% 20($ UC) $\% 20 \mathrm{in} \% 202013$. 


\begin{tabular}{|c|c|c|c|c|c|}
\hline $\begin{array}{l}\text { ELSA COVID- } \\
19 \text { Survey }\end{array}$ & $\begin{array}{l}\text { English } \\
\text { Longitudinal } \\
\text { Study of } \\
\text { Ageing }\end{array}$ & $\begin{array}{l}\text { UK Data } \\
\text { Service }\end{array}$ & $\begin{array}{l}\text { Financial Situation, Mental } \\
\text { / Physical Health, Ethnicity }\end{array}$ & $\begin{array}{l}\text { June/July } \\
\text { and } \\
\text { Nov/Dec } \\
2020\end{array}$ & https://beta.ukdataservice.ac.uk/datacatalogue/... \\
\hline $\begin{array}{l}\text { Family } \\
\text { Resources } \\
\text { Survey }\end{array}$ & $\begin{array}{l}\text { Department } \\
\text { for Work } \\
\text { and } \\
\text { Pensions }\end{array}$ & $\begin{array}{l}\text { UK Data } \\
\text { Service }\end{array}$ & $\begin{array}{l}\text { Income and circumstances } \\
\text { of UK households }\end{array}$ & $\begin{array}{l}2010 / 11- \\
2018 / 19\end{array}$ & https://beta.ukdataservice.ac.uk/datacatalogue/... \\
\hline $\begin{array}{l}\text { Financial } \\
\text { Lives Survey }\end{array}$ & $\begin{array}{l}\text { Financial } \\
\text { Conduct } \\
\text { Authority }\end{array}$ & CDRC & $\begin{array}{l}\text { Financial Situation, Debt, } \\
\text { Home Ownership, } \\
\text { Resilience }\end{array}$ & $\begin{array}{l}2017 \& \\
2020\end{array}$ & https://data.cdrc.ac.uk/dataset/fca-financial-lives-survey \\
\hline $\begin{array}{l}\text { House Price } \\
\text { Index }\end{array}$ & ONS & ONS & $\begin{array}{l}\text { House Prices, Economic } \\
\text { effects of COVID }\end{array}$ & & https://www.gov.uk/government/statistical-data-sets/... \\
\hline $\begin{array}{l}\text { Mind - The } \\
\text { Mental } \\
\text { Health } \\
\text { Charity } \\
\text { COVID } 19 \\
\text { Survey }\end{array}$ & Mind & $\begin{array}{l}\text { On } \\
\text { request } \\
\text { from Mind }\end{array}$ & Mental Health, Ethnicity, & $\begin{array}{l}\text { April/May } \\
2020\end{array}$ & https://www.mind.org.uk/media-a/5929/... \\
\hline $\begin{array}{l}\text { UK Labour } \\
\text { Market Data }\end{array}$ & ONS & ONS & $\begin{array}{l}\text { Labour Market, Ethnicity, } \\
\text { Region }\end{array}$ & Various & https://www.ons.gov.uk/releases/uklabourmarketjune2020 \\
\hline $\begin{array}{l}\text { UKHLS } \\
\text { COVID-19 } \\
\text { Study }\end{array}$ & $\begin{array}{l}\text { University } \\
\text { of Essex }\end{array}$ & $\begin{array}{l}\text { UK Data } \\
\text { Service }\end{array}$ & $\begin{array}{l}\text { Financial Situation, Mental } \\
\text { / Physical Health, } \\
\text { Ethnicity, Local Authority } \\
\text { (On Request), Region }\end{array}$ & $\begin{array}{l}\text { April - } \\
\text { September } \\
2020\end{array}$ & https://beta.ukdataservice.ac.uk/... \\
\hline $\begin{array}{l}\text { Welfare at a } \\
\text { (Social) } \\
\text { Distance }\end{array}$ & $\begin{array}{l}\text { University } \\
\text { of Kent }\end{array}$ & $\begin{array}{l}\text { UK Data } \\
\text { Service }\end{array}$ & $\begin{array}{l}\text { Unemployment, Benefits, } \\
\text { Small Geographies }\end{array}$ & $\begin{array}{l}\text { Collection } \\
\text { in process }\end{array}$ & https://beta.ukdataservice.ac.uk/... \\
\hline OpenSAFELY & $\begin{array}{l}\text { University } \\
\text { of Oxford }\end{array}$ & $\begin{array}{l}\text { University } \\
\text { of Oxford }\end{array}$ & $\begin{array}{l}\text { linked primary care data, } \\
\text { COVID-19 outcome, } \\
\text { ethnicity, cause of death }\end{array}$ & $\begin{array}{l}\text { Collection } \\
\text { in progress }\end{array}$ & https://opensafely.org/ \\
\hline
\end{tabular}


B Figures

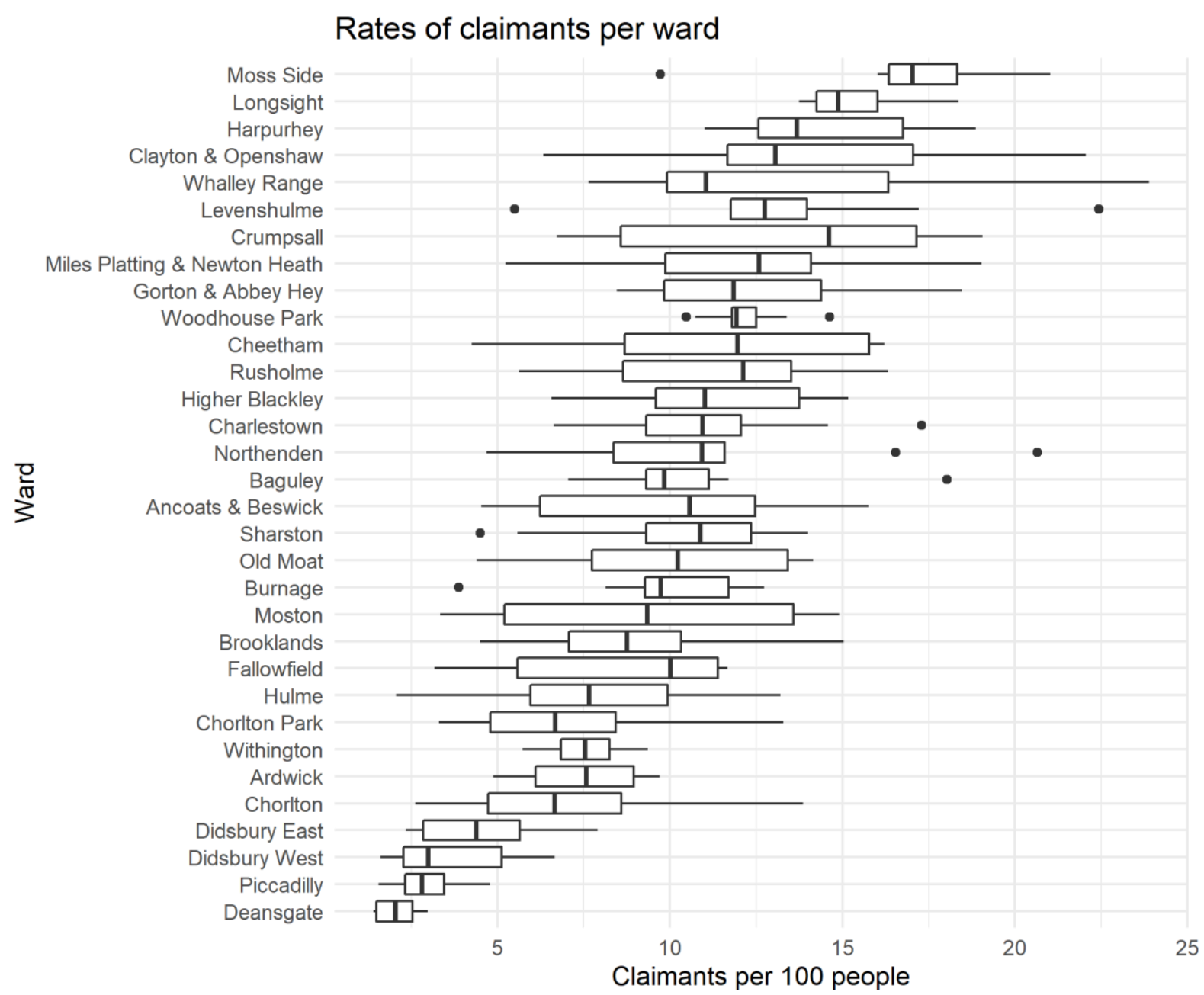

Figure B.1: Rates of benefits claimants per ward, aggregated over LSOAs, Manchester, January 2020 - January 2021. Source: NOMIS database and ONS Mid-2020 Population Estimates for 2020 Wards and 2021 LAs in England and Wales by Single Year of Age and Sex Experimental Statistics. 
a)

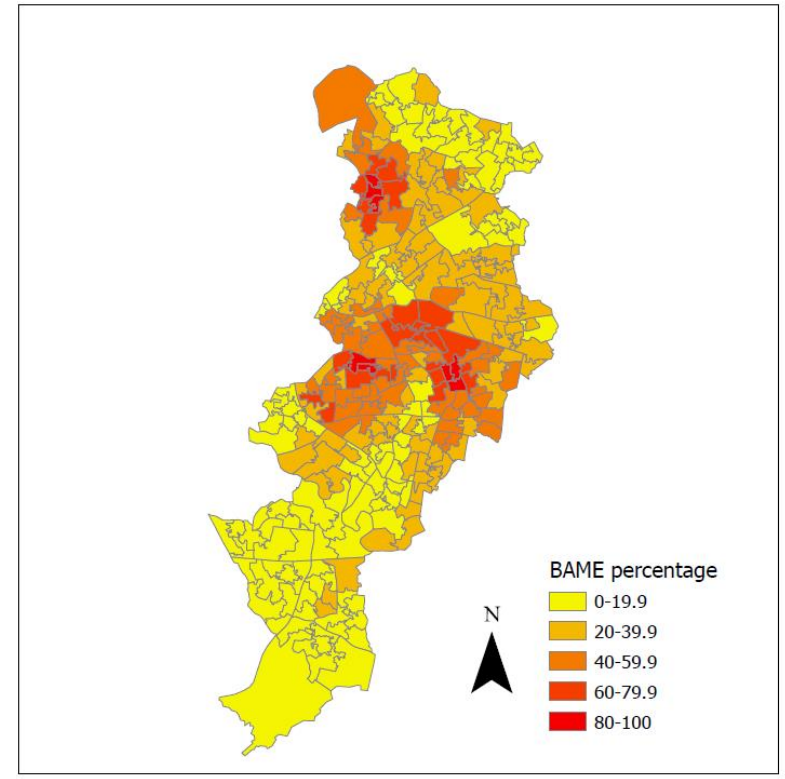

c)

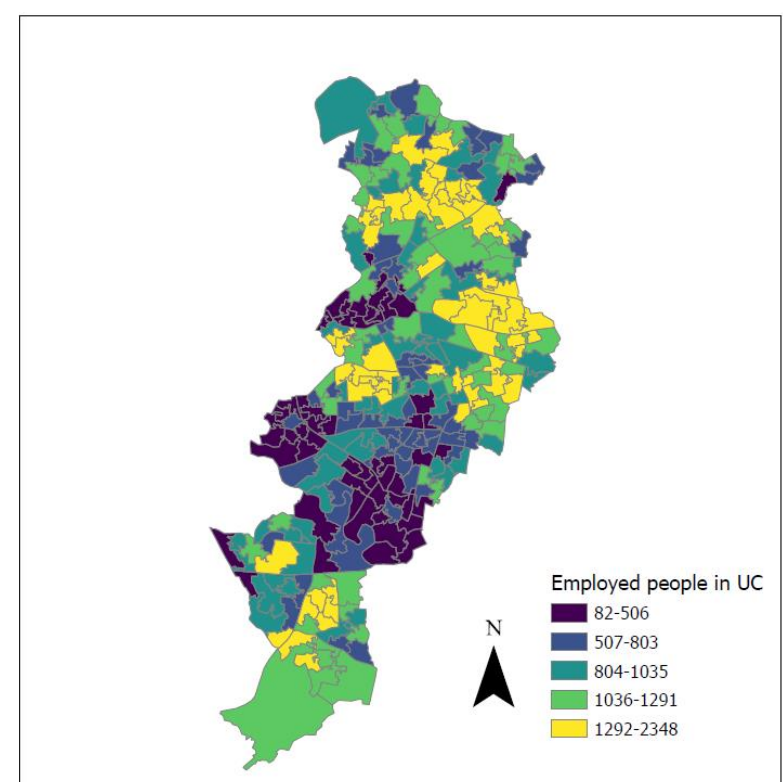

b)

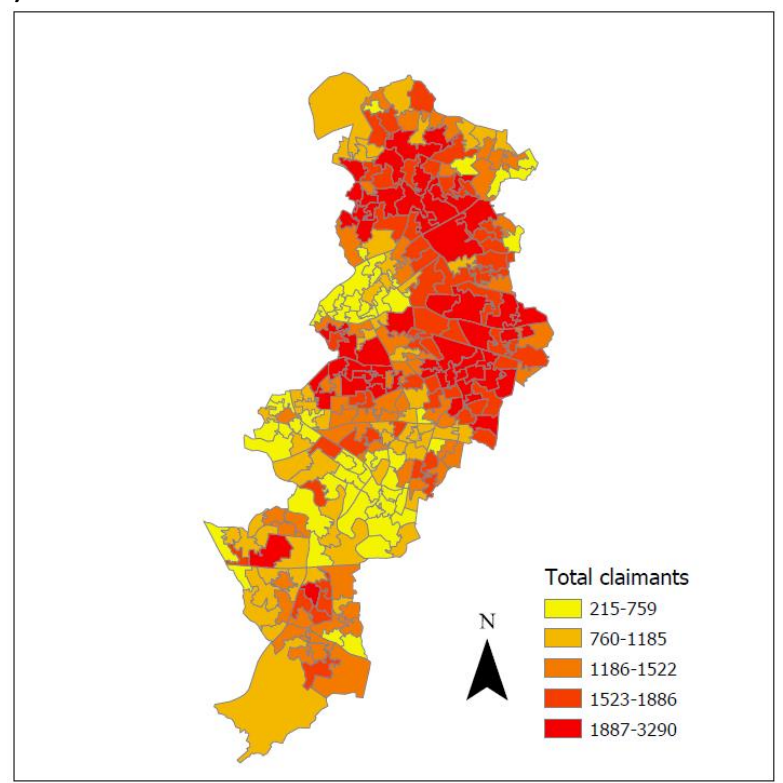

d)

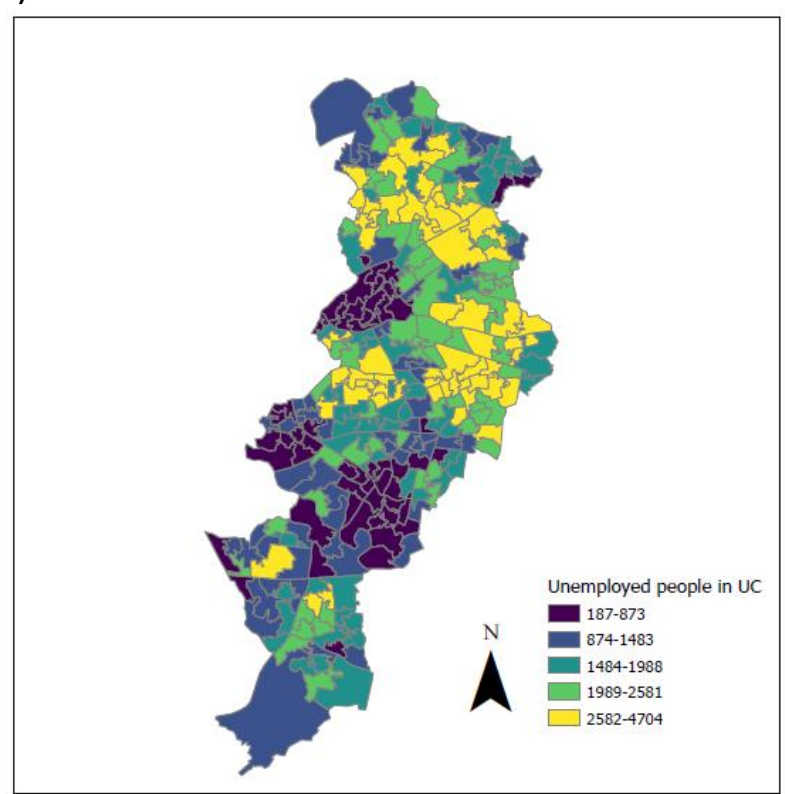

Figure B.2: Percentage of BAME population in LSOAs (panel a), total counts of benefits claimants (b), counts of Universal Credit claimants in employment (c), and counts of Universal Credit claimants unemployed (d) in Manchester district, 2020. Source: own elaboration using NOMIS database. 